\title{
Application of Lemon and Orange Peels in Meat Products: Quality and Safety
}

\author{
Hayam M. Ibrahim ${ }^{1 *}$, Ibrahim M. Hassan² and Ahmed A.M. Hamed ${ }^{1}$ \\ ${ }^{1}$ Food Technology Dept., National Research Center, Dokki, Cairo, Egypt \\ ${ }^{2}$ Food science and Technology Dept., Faculty of Agriculture, Ain Shams University, Egypt \\ *Corresponding author
}

\section{A B S T R A C T}

\begin{tabular}{|l|}
\hline K e y w o r d s \\
$\begin{array}{l}\text { Healthier meat products, } \\
\text { Orange and lemon peels, } \\
\text { Quality and safety } \\
\text { properties, Refrigerated } \\
\text { storage }\end{array}$ \\
\hline Article Info \\
\hline $\begin{array}{l}\text { Accepted: } \\
\text { 23 March } 2018 \\
\text { Available Online: } \\
\text { 10 April 2018 }\end{array}$ \\
\hline
\end{tabular}

\section{Introduction}

Citrus waste is of great value since it contains large amount of various flavonoids, carotenoids, dietary fiber, sugars, polyphenols, essential oils, ascorbic acid, as well some trace elements (Sharma et al., 2017). Total polyphenols and carotenoids in lemons, oranges and grapefruits peels are significantly higher than in the peeled fruits (Ramful et al., 2011).

Lemon and orange peels are considered the primary citrus by-products and discarded as wastes. Re-using these wastes in a suitable form may be of considerable economic benefit

\begin{abstract}
Healthier food products have become a key target for the food industry. Consumer's demands for healthier meat and meat products are rapidly increasing world-wide. In order to improve the functional value of meat product, application of citrus orange or lemon peels (OP or LP) powdered as promising cheap natural functional ingredients in meat patties was carried out. Quality properties and shelf-life of the suggested beef patties as affected by adding citrus peels during refrigeration storage at $4 \pm 1^{\circ} \mathrm{C}$ for 15 days were studied. The addition of 1 or $2 \%$ OP and LP to the beef patties caused a reduction in hiobarbituric acid reactive substances, total volatile basic nitrogen, microbial count, $\mathrm{pH}$ value and shrinkage \%. Somewhat increase in cooking yield, moisture and fat retentions, water \& oil holding capacity were noticed. Also OP or LP powder affected the color, radical scavenging activity, texture and sensory properties relative to control.
\end{abstract}

to food processors due to their valuable technological and nutritional properties which give consumers potential health protection, also, minimize the environmental influence and add value to this residue. Marı'n et al., (2002) reported that most of these materials could be used as functional ingredients when designing healthy foods whereas high content of bioactive compounds present in fruit byproducts can be used as natural food additives, antioxidants, antimicrobials, colorants, flavorings and thickener agents (Ayala-Zavala et al., 2011). Therefore, orange and lemon peels may be viable functional ingredients for different food products such as meat pastes, baked goods and yoghourt. 
It is well known that meat and meat products are important sources of proteins, vitamins, minerals; but they also contain fat, saturated fatty acids, cholesterol, salt, etc. In addition, red meat and processed meat consumption have an increased risk of certain chronic diseases, mainly cardiovascular disease (CVD) and cancer (Jiménez-Colmenero et al., 2012; WHO, 2015; WCRF/AICR, 2007; WHO/FAO, 2003). Meat products can be modified into more "healthier" form by adding beneficial ingredients for health and by removing or reducing harmful components. In this way, a series of food products without changing their base can be obtained and are considered "healthy". This idea of using food for health purposes rather than for nutrition may opens up a whole new field for the meat industry (Zuhaib et al., 2013). Thus, there is interest in development and use of orange and lemon peels "citrus waste" as functional ingredients with antioxidant and antimicrobial through processing healthy meat products to enhance oxidative stability and preserve meat quality for longer shelf life as maintaining food safety according to consumers demand for natural and safe products (Hassan et al., 2017).

So, in the present work the effectiveness of adding orange or lemon peels powder at two levels (1 and $2 \%)$ on some quality properties and shelf-life of the prepared ground beef patties during refrigerated storage at $4 \pm 1{ }^{\circ} \mathrm{C}$ for 15 days was investigated.

\section{Materials and Methods}

Ripened and freshly harvested citrus lemon (Citrus aurantiifolia) and navelat navel orange (Citrus sinensis) fruits were purchased from an Egyptian local market.

Fresh beef lean (from the round) and beef back fat from the same beef carcasses were purchased from a slaughter house at Egyptian local market (Giza, Egypt). Beef meat was used for preparation of beef patties and refrigerated stored at $4 \pm 1{ }^{\circ} \mathrm{C}$ for 15 days.

All chemicals used were of analytical grade and obtained from Sigma Chemical Co. (St. Louis, Mo, USA).

\section{Preparation of lemon and orange peels powder}

Lemon and orange fruits were washed by running tap water, peeled and their edible portions were carefully separated. The obtained fresh citrus peels were cut into small pieces before the drying processes. Then they were dried in microwave oven (type Samsung, 77 QH 400148, MF 2015), with a maximum output of $1500 \mathrm{~W}$ at $2450 \mathrm{MHz}$ ) for $6 \mathrm{~min}$. The dried LP and OP citrus peels were ground to a fine powder using a mechanical laboratory grinder and passed through a 24-mesh sieve, then packaged in polyethylene bags and stored at $4 \pm 1^{\circ} \mathrm{C}$ until required for use.

\section{Preparation of beef patties}

Beef rounds and beef back fat were minced separately through a 3/ 8 inch plate. Minced beef meat was subdivided into five equal parts and beef patties were prepared to provide five treatment samples. A control sample was formulated without any citrus peels addition.

The other four treated samples were prepared by adding $5 \%$ orange or lemon peels suspension as follows: beef patties were formulated with $82 \%$ beef lean, $15 \%$ beef fat, and $3 \%$ cold water as a control, whereas citrus peel treatments were prepared with $80 \%$ beef lean portion, $15 \%$ beef fat, and each $5 \%$ citrus(orange or lemon) peel suspension was prepared (1\% citrus peel and $4 \%$ cold water) or $78 \%$ beef lean portion, $15 \%$ beef fat, and each $7 \%$ citrus peel suspension was prepared (2\% citrus peel and 5\% cold water based on total weight $=100 \%$ ), respectively. All 
ingredients were manually mixed by hand for $5 \mathrm{~min}$, and then, re-minced through a $1 / 4 \mathrm{in}$. plate to be mixed uniformly.

A total of patties (approximately $50 \mathrm{~g}$ each) per treatment were manufactured using a round shape patty maker $(6 \mathrm{~cm} \times 2 \mathrm{~cm})$. Patties were analyzed as fresh samples on the manufacture day. Beef patties were placed on plastic foam meat trays, wrapped with polyethylene film then labeled and stored in a refrigerator at $4 \pm 1^{\circ} \mathrm{C}$ for 15 days. Each group was withdrawn at three days intervals over storage period for analysis.

\section{Analytical methods}

\section{pH determination}

The $\mathrm{pH}$ of citrus peels was determined by blending $10 \mathrm{~g}$ sample with $100 \mathrm{ml}$ distilled water for $1 \mathrm{~min}$. The $\mathrm{pH}$ values were measured using a standardized electrode attached to a digital $\mathrm{pH}$ meter (Cyber scan 500 $\mathrm{pH}$ meter -Serial No 112598).

\section{Color measurement}

Color of each tested sample was measured using a Hunter Lab. scan XE colorimeter (Hunter Lab. Inc., Reston, VA, USA) calibrated with a white standard tile: $(\mathrm{X}=$ 77.26, $\mathrm{Y}=81.94$ and $\mathrm{Z}=88.14)$. Commission International d'Eclairage (CIE): L* (lightness), $\mathrm{a}^{*}$ (redness) and $\mathrm{b}^{*}$ (yellowness) saturation index were measured. Reflectance measurements were collected at $10 \mathrm{~nm}$ increments using illuminate A (Podolak et al., 1997) and three random readings per sample were recorded. Hue and Chroma of citrus peels were calculated by using the formula $\left(\tan ^{-1}\right) b / a$ and $\left(a^{2}+b^{2}\right)^{1 / 2}$ respectively, where a $=$ red unit and $b=$ yellow unit according to Bochi et al., (2008). The redness index $\left(\mathrm{a}^{*} / \mathrm{b}^{*}\right)$ was determined as described by Chen et al., (1997).
Thiobarbituric acid reactive substances (TBARS)

Determination of TBARS value has been found to be a good indicator for lipid oxidation in meat and meat products. TBARS values were determined in minced beef patties samples during refrigerated storage at $4 \pm 1^{\circ} \mathrm{C}$ to evaluate efficiency of additives as natural antioxidants (Pearson, 1991). Ten g of meat samples were mixed with $50 \mathrm{~mL}$ distilled water. Then $2.5 \mathrm{~mL}$ of $4 \mathrm{M} \mathrm{HCl}$ was added to bring the $\mathrm{pH}$ to 1.5 , followed by addition of antifoaming and a few glass beads. The flask was heated by means of an electric mantel, so $50 \mathrm{~mL}$ distillate was collected in $10 \mathrm{~min}$ from the time of boiling commences. Five $\mathrm{mL}$ of the distillate was mixed with $5 \mathrm{~mL}$ of TBA solution $(0.2883 \mathrm{gm} \mathrm{TBA} / 100 \mathrm{~mL}$ of $90 \%$ glacial acetic acid) in a glass-stopper tube. Blank was carried out using $5 \mathrm{~mL}$ distilled water and $5 \mathrm{~mL}$ TBA solution. Tubes were covered and heated in boiling water bath for $35 \mathrm{~min}$, then after rapid cooling in ice bath, absorbance at $538 \mathrm{~nm}$ was measured against the blank using ultraviolet visible scanner spectrophotometer $(\mathrm{T} 80+\mathrm{UV} / \mathrm{V}$ is Spectrophotometer PG instrument Ltd). The TBARS values were calculated by multiplying the absorbance by the factor of 7.8 and the result was represented as $\mathrm{mg}$ of malonaldehyde per $\mathrm{kg}$ sample.

\section{Total volatile basic nitrogen (TVBN)}

It is known that TVBN are products of bacterial decomposition and the content is extensively used as an index to assess the keeping quality and shelf life of meat and meat products (Pearson, 1991). The method recommended for determination of TVBN is based on a semi-micro distillation procedure. Weigh $10 \mathrm{gm}$ of minced meat samples plus 2gm magnesium oxide $(\mathrm{MgO})$ into a semimicro-distillation apparatus, and then add 300 $\mathrm{mL}$ tap water and antifoam materials. Steam 
distilled collect in $25 \mathrm{~mL} 2 \%$ boric acid containing kjeldahl indicator solution which exhibited blue color. Kjeldahl flask was heated for $10 \mathrm{~min}$, then distillate for another $15 \mathrm{~min}$ from the time of boiling commences, so $\sim 150 \mathrm{~mL}$ distillate was collected into boric containing flask, the color became light green after fixing the ammonia " $\mathrm{NH}_{3}$ ". Titrate to a pale blue end point with $0.1 \mathrm{~N} \mathrm{H}_{2} \mathrm{SO}_{4}$ solution. The TVBN values were calculated by multiplying the reading minus the blank by the factor of 14. The results were represented as mg N per 100gm sample.

\section{Radical scavenging activity (DPPH)}

The effect of used (OP and LP) citrus peels extracts on 1,1-diphenyl-2-picrylhydrazyl (DPPH) free radical was estimated in order to assess the antioxidant capacity according to the procedure described by (Yi et al., 2008) with some modifications. The reaction mixture was incubated for $30 \mathrm{~min}$ in darkness at room temperature. The absorbance of the resulting solution was measured at $517 \mathrm{~nm}$ using spectrophotometer (T80 UV/ Visible - PG instrument Ltd - Made in Germany). For the control, the assay was conducted in the same manner but ethanol was used instead of sample solution. DPPH scavenging capacity of the tested samples was measured as a decrease in the absorbance and was calculated by using the following equation:

Scavenging activity $(\%)=$ Ac - As $/$ Ac X100

Where Ac and As are the absorbance's at 517 $\mathrm{nm}$ of the control and sample, respectively.

\section{Microbiological preparation of medium used for T.P.C}

Total plate count (T.P.C) of the control and treated beef samples were evaluated by plating on nutrient agar medium (N.A) according to the recommended method of (Frazier and
Foster, 1950), However, its composition was prepared according to the method described by Difco Manual (1998) as follows: Beef extract (3gm), sodium chloride (5gm), peptone (5gm), agar $(15 \mathrm{gm})$, distilled water up to $(1 \mathrm{~L})$ and modified $\mathrm{pH}$ of the medium to $6.8 \pm 0.2$. These ingredients were mixed thoroughly, boiled to dissolve them then dispensed into flasks and autoclaved at $121^{\circ} \mathrm{C}$ for $15 \mathrm{~min}$ and then cool to about $45^{\circ} \mathrm{C}$ and pour into sterilized plates. Ten grams of representative minced beef patty samples were mixed with $90 \mathrm{~mL}$ peptone in $250 \mathrm{~mL}$ flask under aseptic conditions. The suspension was shaked by hand for $5 \mathrm{~min}$ to give $1 / 10$ dilution. Serial dilutions were prepared to be used for counting bacteria.

\section{Total plate count (T.P.C)}

One $\mathrm{ml}$ from each prepared dilution was plated on the above medium in triplicates and incubated at $37{ }^{\circ} \mathrm{C}$ for $48 \mathrm{hr}$. The count was then calculated and expressed as colonies per gram flesh.

\section{Cooking characteristics}

Cooking yield was determined in quadruplicate by the weight differences between raw and cooked patties. Four beef patties per treatment were cooked in a preheated electric grill $\left(135^{\circ} \mathrm{C}\right)$ until the targeted core temperature reached $71^{\circ} \mathrm{C}$ monitored by using a digital thermometer equipped with a data logger according to Kim et al., (2016). To estimate the amount of fat and moisture retained in the samples, the following calculations were performed:

$\%$ cooking yield $=100[$ cooked weight $(\mathrm{g}) /$ raw weight $(\mathrm{g})]$

$\%$ fat retention $=100($ cooked weight $(\mathrm{g}) \times \%$ fat in cooked samples) / (raw weight $(\mathrm{g}) \times \%$ fat in raw samples) 
$\%$ moisture retention $=100$ (cooked weight $(\mathrm{g})$ $\times \%$ moisture in cooked samples) / (raw weight $(\mathrm{g}) \times \%$ moisture in raw samples)

$\%$ Shrinkage $=$ Raw thickness - cooked thickness $+[($ Raw diameter - cooked diameter) / (Raw thickness + raw diameter)] $\times$ 100

Water \& oil holding capacities were determined.

\section{Sensory evaluation of beef patties}

The sensory attributes (appearance, odor, texture, taste and overall acceptability) of the freshly cooked beef patties samples were evaluated using a 10-point numerical scale; where ten corresponded to "the highest quality", a score less than 4 indicate that the sample is "rejected" (Watts et al., 1989).

\section{Texture profile analysis}

Texture profile analyses were performed from four patties described by Claus and Sørheim (2006) using a Texture Analyzer (Cometech, B type, Taiwan).

\section{Results and Discussion}

Lipid oxidation, microbial growth and color changes are important factors for shelf-life and consequently for consumer acceptance of fresh meat (Hayes et al., 2010; Pavelková et al., 2013). Natural preservatives can protect the human body from free radicals and can retard the progress of many chronic diseases as well lipid oxidation and microbial growth in foods due to their phenolic compounds (Camo et al., 2008; APHA, 2001).

\section{Thiobarbituric acid reactive substances (TBARS)}

The TBARS method has been widely used to determine the degree of lipid oxidation
(Klangpetch et al., 2016) and used as an index of lipid oxidation in meat products during storage (Fernández-López et al., 1997 and Pearson, 1991). Data in Table 1 and Figure 1 show the changes in TBARS values of the prepared ground beef patties during refrigerated storage for 15 days at $4 \pm 1^{\circ} \mathrm{C}$. Results indicated that TBARS values increased over the storage time for all patty samples. Control raw patties exhibited significantly higher TBARS values at any given time of chilling as compared to $1 \& 2 \%$ OP and 1 and 2\% LP formulated patties.

TBARS till 12 days at $4^{\circ} \mathrm{C}$ as indicated by their lower TBARS (less than $0.9 \mathrm{mg}$ MDA $\mathrm{kg}^{-1}$ meat) according to the (ES 1694/2005) for meat products, versus to only nine days for control samples. Worthy to note that samples with high concentration of OP or LP (2\%) showed good quality till 15 days refrigerated storage under the same conditions (Table 1 and Fig. 1). The obtained results agreed Klangpetch et al., (2016) who reported that TBARS values increased considerably in control (2.5 mg MDA/kg sample) but remained relatively low in lime peel-treated samples with no significant differences at all concentration (1.5-1.8 mg MDA/kg sample). At 14 days, lime peel (Citrus aurantifolia Swingle) reduced the lipid oxidation for more than 40\%. However, the malonaldehyde (MDA) accumulation in patties during refrigerated storage could be due to hydrolytic and oxidative processes in the lipid fraction (Brake and Fennema 1999). The high efficiencies found in OP or LP were closely confirming the key role of these phenolic compounds as scavengers of free radicals and as primary, chain breaking antioxidants (Hanan et al., 2013; Wang et al., 1996; Brunton et al., 2000; Mielnik et al., 2006).

\section{Total volatile basic nitrogen (TVBN)}

TVBN is considered the most commonly used biochemical methods for assessing meat 
spoilage (Pearson, 1991). TVBN changes of beef patties sample are illustrated in Table 2 and Figure 2). At the beginning of storage (zero day) control, $1 \%, 2 \% \mathrm{OP}, 1 \%$ and $2 \%$ LP patties sample exhibit 10.80, 10.61, 10.46, 10.50 and $10.30 \mathrm{mg} \mathrm{N} / 100 \mathrm{~g}$ sample; respectively. This is an indication of good quality raw material used in this assay and similar to some reported previous results by EL-Desouky et al., (2006) and Moawad et al., (2000). Also, TVBN of all patties sample gradually increased with different rates depending on amount of the addition and time of storage (Fig. 2).

At 15 days of storage, TVBN reached 28.06, 24.16, 18.35, 23.81 and $17.95 \mathrm{mg} \mathrm{N} / 100 \mathrm{~g}$ for control and other samples respectively. The increase noticed in TVBN values is related to the activity of spoilage bacteria and endogenous enzymes (Pearson, 1991). The lower TVBN for samples with OP or LP may be due to the effect of the bioactive compounds in citrus peel on microorganisms. Concerning TVBN values as a spoilage index for meat products, a level above $20 \mathrm{mg} \mathrm{N} / 100$ g sample is usually considered spoiled minced meat (ES 1694/2005). Accordingly, in the present study control beef patties was acceptable with regard to TVBN index for 8 days only i.e. at $9^{\text {th }}$ day its level reached to $20.36 \mathrm{mg}$ N/100 g sample. During storage period, the TVBN of patties with orange and lemon peels powder was lower than the control sample up to 12 days only, whereas $2 \%$ OP and 2\% LP addition extended the shelf-life to 15 days under the same conditions. These results confirmed Mexis et al., (2012).

\section{Radical scavenging activity (DPPH)}

From the data in Table 3 and Figure 3 the DPPH values of beef patties mixed with citrus peels during refrigerated storage, showed that patties sample with $2 \%$ LP gave the greatest $\%$
DPPH $(7.91 \%)$ followed by $2 \%$ OP then $1 \%$ LP and $1 \%$ OP compared to control at zero time. The DPPH \% activity decreased during refrigerated storage in all patties sample. Hayam and Ferial (2013) revealed that the addition of lemongrass and lime peel extracts to the chicken patties sample stored at $4{ }^{\circ} \mathrm{C}$ for 9 days was effective as antioxidant and antimicrobial agents. Those treatments improved the properties of the prepared chicken patties from a quality and safety view point.

In addition, antioxidants are believed to intercept the free radical chain of oxidation and to give hydrogen from the phenolic hydroxyl groups, there, by forming a stable end product that does not initiate or propagate further oxidation of lipids (Sherwin, 1998).

\section{Microbiological properties}

Total plate counts (TPC) of beef patties were evaluated and the counts (as $\log 10 \mathrm{CFU} / \mathrm{gm}$ ) are presented in Table 4 and Figure 4. The shelf-life of control meat is usually limited by microbial spoilage. Depending on hygiene and preservation conditions, raw beef patties stored aerobically have a shelf-life of around 7-8 days in refrigerated conditions (Sallam and Samejima, 2004; Hayes et al., 2010). The same Table and Figure revealed that a slight higher in TPC value was noticed in control sample when compared with other treatments at zero time of cold storage; which indicated that OP and LP caused sudden lethal effect for microorganisms. As might be expected, the increase in storage time produced significant increase greatly in TPC, whatever the treatment condition.

Storage time have a significant effect on TPCs of raw beef patties (Table 4 and Fig. 4). However, by the day 9 of storage, TPC of control sample (7.77) exceeded the maximal recommended limit of $7 \log 10 \mathrm{CFU} / \mathrm{gm}$ for 
TPC in raw meat (ICMSF, 1986) indicating a shelf life of about 8 days. While, $1 \%$ OP and LP-treatments significantly delayed the microbial growth and extended the shelf life of the product up to 12 days at which the TPC was 5.76 and 5.66 versus $8.88 \log 10 \mathrm{CFU} / \mathrm{gm}$ in control samples. Also it was revealed that at the 15th day of storage, samples containing $2 \%$ OP and LP had lower TPC value (6.26 and $5.98 \log 10 \mathrm{CFU} / \mathrm{gm})$ than the maximal recommended limit, while control samples exhibited a higher count of $10.11 \log 10$ $\mathrm{CFU} / \mathrm{gm}$, these indicating that as the OP and LP concentration increased in the formula, the TPC of the samples decreased. Similar results were achieved by (Alahakoon et al., 2013) who found that significant effects of citrus peel extract and onion peel extract added to chicken breast meat sample on microbial growth inhibition during storage at different temperatures. Klangpetch et al., (2016) reported also that total viable count (TVC) of all samples increased during storage. Lime peel reduced TVC soon after dipping, to be lower than control and water for 2 and 1.2 logorders during 6 to 10 days of storage.

\section{Functional and physical properties}

\section{Water and oil holding capacities}

Water-holding capacity (WHC) is one of the major quality properties of fresh meat as it affects some major characteristics such as potential drip loss, technological quality, appearance and sensory properties (Das et al., 2011). WHC of meat is considered as an important factor affects tenderness, thawing drip and cooking loss of meat (Hamm, 1986). Also it is one of important measurements of quality attributes for possibility of using meat in manufacturing of any meat products. This property is largely affected by the muscles proteins and $\mathrm{pH}$ value level. Generally WHC decline continuously with the progression of storage period.
Oil-holding capacity (OHC) is also a technological property related to the chemical structure of the plant polysaccharides and depends on surface properties, overall charge density, thickness, and hydrophobic nature of the fiber particle (Fernandez-Lopez et al., 2009 and Figuerola et al., 2005).

Effect of adding orange and lemon peels powder on water and oil holding capacities of the tested beef patties are presented in Table 5 .

The lowest OHC and WHC values were noticed for control beef patties samples compared to other formulated samples. The $\mathrm{OHC}$ and WHC of the tested patties sample decreased slightly during storage due to the addition of powdered citrus peel. The OHC increased in beef patties samples contained $2 \%$ lemon peel followed by $2 \%$ orange peel, $1 \%$ lemon peel and $1 \%$ orange peel compared with the control. Similar trends were found in case WHC of the above meat samples. ViudaMartos et al., (2012) mentioned that WHC is related to soluble dietary fiber (SDF) content, and high levels of SDF produce a high WHC value. This could be explained by the higher WHC of soluble fibers, such as pectin and gums than cellulosic fibers. So, the higher WHC of LP and OP could be due to the chemical structures, which possess a higher WHC than cellulosic fibers in citrus peel. All the tested samples showed decrease WHC during refrigerated beef patties. Such effects could be attributed not only to particle size reduction, but also to the altering of the fiber matrix structure. Kethireddipalli et al., (2002) reported that WHC depends on matrix structure formed by polysaccharide chains which can hold large amounts of water through hydrogen bonds. Also, Sangnark and Noomhorm, (2003) reported that particle size reduction of dietary fibers has been associated with a lower ability to retain water and a lower oil binding capacity. 


\section{pH value}

Meat $\mathrm{pH}$ is considered as one of the most important technological properties as it alters pigment and lipid stability. Changes in $\mathrm{pH}$ values in ground beef during cold storage at $4 \pm 1^{\circ} \mathrm{C}$ for 15 days are presented in Table 6 and Figure 5. $\mathrm{pH}$ value of control sample at zero time of storage is 6.01 . The $\mathrm{pH}$ values of raw samples (mixed with $1 \& 2 \%$ OP or LP) obviously decreased to be less than 6.00 (slight acidic values). This decrease could be due to the presence of some organic acids in OP and/or LP which shifted the control sample to be less slightly acidic. Braddock, (1995) reported that the $\mathrm{pH}$ values of samples with added lemon albedo were lower than control samples due to the presence of some organic acids.

\section{Instrumental color measurements of beef patties}

Instrumental color evaluation (Table 7) revealed a significant $(\mathrm{P} \leq 0.05)$ effect of 1 and $2 \%$ of lemon peel or orange peel powder on Hunter color parameters values of all formulated beef patties sample. Color lightness $\left(\mathrm{L}^{*}\right)$ values of control sample was increased all over the storage period and the reverse pattern occurred for $\mathrm{a}^{*}($ redness) and $b^{*}$ (Yellowness) color values.

Table.1 TBARS values changes of beef patty samples during refrigerated storage at $4 \pm 1{ }^{\circ} \mathrm{C}$ for 15 days

\begin{tabular}{|l|c|c|c|c|c|c|}
\hline $\begin{array}{l}\text { Beef } \\
\text { patty } \\
\text { Samples }\end{array}$ & 0 & 3 & 6 & 9 & 12 & 15 \\
\hline Control & $0.46^{\mathrm{a}} \pm 0.01$ & $0.59^{\mathrm{a}} \pm 0.01$ & $0.80^{\mathrm{a}} \pm 0.01$ & $1.20^{\mathrm{a}} \pm 0.01$ & $1.45^{\mathrm{a}} \pm 0.01$ & $1.73^{\mathrm{a}} \pm 0.01$ \\
\hline $1 \%$ OP & $0.41^{\mathrm{b}} \pm 0.01$ & $0.52^{\mathrm{b}} \pm 0.01$ & $0.63^{\mathrm{b}} \pm 0.01$ & $0.75^{\mathrm{b}} \pm 0.01$ & $0.91^{\mathrm{b}} \pm 0.00$ & $1.31^{\mathrm{b}} \pm 0.01$ \\
\hline $2 \%$ OP & $0.37^{\mathrm{c}} \pm 0.01$ & $0.48^{\mathrm{c}} \pm 0.01$ & $0.57^{\mathrm{d}} \pm 0.01$ & $0.66^{\mathrm{d}} \pm 0.00$ & $0.80^{\mathrm{d}} \pm 0.01$ & $0.92^{\mathrm{d}} \pm 0.01$ \\
\hline $1 \%$ LP & $0.39^{\mathrm{b}} \pm 0.02$ & $0.51^{\mathrm{b}} \pm 0.00$ & $0.62^{\mathrm{c}} \pm 0.01$ & $0.72^{\mathrm{c}} \pm 0.01$ & $0.90^{\mathrm{c}} \pm 0.00$ & $1.27^{\mathrm{c}} \pm 0.01$ \\
\hline $2 \%$ LP & $0.35^{\mathrm{d}} \pm 0.01$ & $0.46^{\mathrm{d}} \pm 0.00$ & $0.55^{\mathrm{e}} \pm 0.00$ & $0.61^{\mathrm{e}} \pm 0.01$ & $0.77^{\mathrm{e}} \pm 0.00$ & $0.91^{\mathrm{e}} \pm 0.01$ \\
\hline
\end{tabular}

All values are mean of triplicate determinations \pm standard deviation (SD). Mean values in the same column bearing the same superscript do not differ significantly $(\mathrm{P}>0.05)$. Thiobarbituric acid reactive substances (TBARS, as $\mathrm{mg}$ of malonaldehyde per Kg sample) OP= Orange Peel and LP= Lemon Peel.

Table.2 Total volatile basic nitrogen (mg N/100gm sample) changes of beef patties during refrigerated storage at $4 \pm 1{ }^{\circ} \mathrm{C}$ for 15 days

\begin{tabular}{|l|c|c|c|c|c|c|}
\hline $\begin{array}{l}\text { Beef } \\
\text { patty } \\
\text { Samples }\end{array}$ & 0 & 3 & 6 & 9 & 12 & 15 \\
\hline Control & $10.80^{\mathrm{a}} \pm 0.01$ & $13.27^{\mathrm{a}} \pm 0.01$ & $16.46^{\mathrm{a}} \pm 0.02$ & $20.36^{\mathrm{a}} \pm 0.02$ & $25.04^{\mathrm{a}} \pm 0.04$ & $28.06^{\mathrm{a}} \pm 0.03$ \\
\hline $1 \%$ OP & $10.61^{\mathrm{b}} \pm 0.01$ & $11.70^{\mathrm{b}} \pm 0.01$ & $13.01^{\mathrm{b}} \pm 0.02$ & $16.41^{\mathrm{b}} \pm 0.02$ & $19.65^{\mathrm{b}} \pm 0.02$ & $24.16^{\mathrm{b}} \pm 0.02$ \\
\hline $2 \%$ OP & $10.46^{\mathrm{d}} \pm 0.01$ & $10.51^{\mathrm{d}} \pm 0.02$ & $11.60^{\mathrm{d}} \pm 0.02$ & $13.70^{\mathrm{d}} \pm 0.02$ & $15.65^{\mathrm{d}} \pm 0.02$ & $18.35^{\mathrm{d}} \pm 0.01$ \\
\hline $1 \%$ LP & $10.50^{\mathrm{c}} \pm 0.02$ & $11.50^{\mathrm{c}} \pm 0.00$ & $12.75^{\mathrm{c}} \pm 0.01$ & $16.07^{\mathrm{c}} \pm 0.04$ & $19.34^{\mathrm{c}} \pm 0.03$ & $23.81^{\mathrm{c}} \pm 0.02$ \\
\hline $\mathbf{2 \% L P}$ & $10.30^{\mathrm{e}} \pm 0.04$ & $10.40^{\mathrm{e}} \pm 0.01$ & $11.45^{\mathrm{e}} \pm 0.01$ & $13.46^{\mathrm{e}} \pm 0.02$ & $15.40^{\mathrm{e}} \pm 0.02$ & $17.95^{\mathrm{e}} \pm 0.02$ \\
\hline
\end{tabular}

All values are mean of triplicate determinations \pm standard deviation (SD). Mean values in the same column bearing the same superscript do not differ significantly $(\mathrm{P}>0.05)$. $\mathrm{OP}=$ Orange Peel and $\mathrm{LP}=$ Lemon Peel. 
Table.3 Changes radical scavenging activity (DPPH \%) values of beef patty samples during refrigerated storage at $4 \pm 1{ }^{\circ} \mathrm{C}$ for 15 days

\begin{tabular}{|c|c|c|c|c|c|c|}
\hline \multirow{2}{*}{$\begin{array}{l}\text { Beef patty } \\
\text { Samples }\end{array}$} & \multicolumn{6}{|c|}{ Refrigerated Storage $\left(4^{\circ} \mathrm{C}\right)$ per day } \\
\hline & 0 & 3 & 6 & 9 & 12 & 15 \\
\hline Control & $01.83^{\mathrm{e}} \pm 0.03$ & $0.90^{\mathrm{e}} \pm 0.03$ & $0.08^{\mathrm{e}} \pm 0.03$ & $0.02^{\mathrm{e}} \pm 0.04$ & $0.00^{\mathrm{e}} \pm 0.00$ & $0.00^{\mathrm{c}} \pm 0.00$ \\
\hline $1 \% \mathrm{OP}$ & $21.22^{d} \pm 0.10$ & $16.52^{d} \pm 0.03$ & $10.79^{d} \pm 0.03$ & $6.55^{\mathrm{d}} \pm 0.03$ & $1.58^{\mathrm{d}} \pm 0.03$ & $0.02^{c} \pm 0.03$ \\
\hline $2 \% \mathrm{OP}$ & $32.08^{b} \pm 0.03$ & $28.23^{b} \pm 0.68$ & $23.53^{b} \pm 0.03$ & $19.57^{\mathrm{b}} \pm 0.1$ & $13.31^{\mathrm{b}} \pm 0.03$ & $6.51^{\mathrm{b}} \pm 0.12$ \\
\hline $1 \% \mathrm{LP}$ & $23.61^{c} \pm 0.03$ & $18.39^{\mathrm{c}} \pm 0.45$ & $13.98^{c} \pm 0.47$ & $9.80^{\mathrm{c}} \pm 0.07$ & $3.69^{c} \pm 0.03$ & $0.06^{c} \pm 0.06$ \\
\hline $2 \% \mathrm{LP}$ & $34.01^{\mathrm{a}} \pm 0.10$ & $29.03^{\mathrm{a}} \pm 0.2$ & $25.19^{\mathrm{a}} \pm 0.2$ & $21.17^{\mathrm{a}} \pm 0.07$ & $16.38^{\mathrm{a}} \pm 0.10$ & $7.91^{\mathrm{a}} \pm 0.07$ \\
\hline
\end{tabular}

All values are mean of triplicate determinations \pm standard deviation (SD). Mean values in the same column bearing the same superscript do not differ significantly $(\mathrm{P}<0.05)$. OP=Orange Peel and LP= Lemon Peel

Table.4 Total plate count changes of beef patty samples during refrigerated storage at $4 \pm 1{ }^{\circ} \mathrm{C}$ for 15 days (as $\log 10 \mathrm{CFUgm}^{-1}$ )

\begin{tabular}{|l|c|c|c|c|c|c|}
\hline $\begin{array}{l}\text { Beef patty } \\
\text { Samples }\end{array}$ & \multicolumn{7}{|c|}{ Refrigerated Storage $\left(4^{\circ} \mathrm{C}\right)$ per day } \\
\hline Control & $4.97^{\mathrm{a}} \pm 0.04$ & $6.05^{\mathrm{a}} \pm 0.05$ & $7.43^{\mathrm{a}} \pm 0.06$ & $7.77^{\mathrm{a}} \pm 0.15$ & $8.88^{\mathrm{a}} \pm 0.14$ & $10.11^{\mathrm{a}} \pm 0.07$ \\
\hline $1 \%$ OP & $3.46^{\mathrm{b}} \pm 0.11$ & $3.63^{\mathrm{b}} \pm 0.07$ & $4.83^{\mathrm{b}} \pm 0.04$ & $5.65^{\mathrm{b}} \pm 0.13$ & $5.76^{\mathrm{b}} \pm 0.07$ & $7.41^{\mathrm{b}} \pm 0.02$ \\
\hline $2 \%$ OP & $1.90^{\mathrm{c}} \pm 0.24$ & $3.05^{\mathrm{c}} \pm 0.31$ & $3.53^{\mathrm{c}} \pm 0.06$ & $4.89^{\mathrm{c}} \pm 0.15$ & $5.69^{\mathrm{b}} \pm 0.10$ & $6.26^{\mathrm{d}} \pm 0.01$ \\
\hline $1 \%$ LP & $3.27^{\mathrm{b}} \pm 0.13$ & $3.48^{\mathrm{b}} \pm 0.11$ & $4.72^{\mathrm{b}} \pm 0.08$ & $5.56^{\mathrm{b}} \pm 0.06$ & $5.66^{\mathrm{b}} \pm 0.05$ & $7.03^{\mathrm{c}} \pm 0.09$ \\
\hline $2 \%$ LP & $1.35^{\mathrm{c}} \pm 0.91$ & $2.87^{\mathrm{c}} \pm 0.2$ & $3.39^{\mathrm{c}} \pm 0.17$ & $4.63^{\mathrm{c}} \pm 0.07$ & $4.75^{\mathrm{c}} \pm 0.11$ & $5.98^{\mathrm{e}} \pm 0.10$ \\
\hline
\end{tabular}

All values are mean of triplicate determinations \pm standard deviation (SD). Mean values in the same column bearing the same superscript do not differ significantly $(\mathrm{P}<0.05)$. Total plate count as $\log 10 \mathrm{CFUgm}^{-1}$, OP: Orange Peel and LP: Lemon Peel.

Table.5 Water and oil holding capacity values changes of beef patties sample during refrigerated storage at $4 \pm 1{ }^{\circ} \mathrm{C}$ for 15 days

\begin{tabular}{|c|c|c|c|c|c|c|}
\hline \multirow{2}{*}{$\begin{array}{l}\text { Beef patty } \\
\text { Samples }\end{array}$} & \multicolumn{6}{|c|}{ Refrigerated Storage (day) } \\
\hline & 0 & 3 & 6 & 9 & 12 & 15 \\
\hline & \multicolumn{6}{|c|}{ Water Holding Capacity } \\
\hline Control & $1.50^{\mathrm{c}} \pm 0.04$ & $1.35^{\mathrm{c}} \pm 0.02$ & $1.11^{\mathrm{c}} \pm 0.10$ & $0.50^{c} \pm 0.03$ & $0.11^{\mathrm{e}} \pm 0.01$ & $0.01^{\mathrm{d}} \pm 0.01$ \\
\hline $1 \% \mathrm{OP}$ & $3.86^{\mathrm{b}} \pm 0.05$ & $3.72^{b} \pm 0.07$ & $3.56^{\mathrm{b}} \pm 0.03$ & $3.11^{\mathrm{b}} \pm 0.10$ & $2.81^{\mathrm{d}} \pm 0.02$ & $2.71^{\mathrm{c}} \pm 0.02$ \\
\hline $2 \% \mathrm{OP}$ & $4.02^{\mathrm{a}} \pm 0.06$ & $3.85^{\mathrm{a}} \pm 0.05$ & $3.71^{\mathrm{a}} \pm 0.02$ & $3.40 \pm 0.04^{\mathrm{a}}$ & $3.23^{\mathrm{b}} \pm 0.03$ & $3.14^{\mathrm{a}} \pm 0.04$ \\
\hline $1 \% \mathrm{LP}$ & $3.87^{\mathrm{b}} \pm 0.03$ & $3.74^{\mathrm{b}} \pm 0.02$ & $3.59^{\mathrm{b}} \pm 0.02$ & $3.13^{b} \pm 0.10$ & $2.94^{\mathrm{c}} \pm 0.02$ & $2.80^{\mathrm{b}} \pm 0.05$ \\
\hline \multirow[t]{2}{*}{$2 \% \mathrm{LP}$} & $.04^{\mathrm{a}} \pm 0.11$ & $3.90^{\mathrm{a}} \pm 0.03$ & $3.77^{\mathrm{a}} \pm 0.01$ & $3.47^{\mathrm{a}} \pm 0.04$ & $3.29^{\mathrm{a}} \pm 0.02$ & $3.18^{\mathrm{a}} \pm 0.02$ \\
\hline & \multicolumn{6}{|c|}{ Oil Holding Capacity } \\
\hline Control & $0.70^{c} \pm 0.02$ & $0.60^{c} \pm 0.03$ & $0.42^{\mathrm{e}} \pm 0.01$ & $0.18^{\mathrm{e}} \pm 0.02$ & $0.05^{\mathrm{e}} \pm 0.00$ & $0.00^{\mathrm{e}} \pm 0.00$ \\
\hline $1 \% \mathrm{OP}$ & $1.05^{\mathrm{b}} \pm 0.10$ & $0.91^{\mathrm{b}} \pm 0.01$ & $0.75^{d} \pm 0.01$ & $0.60^{\mathrm{d}} \pm 0.01$ & $0.50^{\mathrm{d}} \pm 0.01$ & $0.21^{\mathrm{d}} \pm 0.01$ \\
\hline $2 \% \mathrm{OP}$ & $1.50^{\mathrm{a}} \pm 0.09$ & $1.48^{\mathrm{a}} \pm 0.03$ & $1.35 \pm 0.02^{b}$ & $1.23^{\mathrm{b}} \pm 0.01$ & $1.09^{b} \pm 0.03$ & $0.93^{\mathrm{b}} \pm 0.01$ \\
\hline $1 \% \mathrm{LP}$ & $1.07^{\mathrm{b}} \pm 0.04$ & $0.92^{b} \pm 0.01$ & $0.91^{\mathrm{c}} \pm 0.01$ & $0.78^{\mathrm{c}} \pm 0.01$ & $0.69^{c} \pm 0.03$ & $0.35^{\mathrm{c}} \pm 0.01$ \\
\hline $2 \% \mathrm{LP}$ & $1.59^{a} \pm 0.03$ & $1.51^{\mathrm{a}} \pm 0.04$ & $1.47^{\mathrm{a}} \pm 0.04$ & $1.37^{\mathrm{a}} \pm 0.06$ & $1.28^{\mathrm{a}} \pm 0.04$ & $1.05^{\mathrm{a}} \pm 0.05$ \\
\hline
\end{tabular}

All values are mean of triplicate determinations \pm standard deviation (SD). Mean values in the same column bearing the same superscript do not differ significantly $(\mathrm{P}>0.05)$. $\mathrm{OP}=$ Orange Peel and $\mathrm{LP}=$ Lemon Peel 
Table.6 $\mathrm{pH}$ changes of beef patties during refrigerated storage at $4 \pm 1^{\circ} \mathrm{C}$ for 15 days

\begin{tabular}{l|c|c|c|c|c|c|}
\hline $\begin{array}{l}\text { Beef patty } \\
\text { Samples }\end{array}$ & 0 & 3 & 6 & 9 & 12 & 15 \\
\hline Control & $6.01^{\mathrm{a}} \pm 0.01$ & $6.20^{\mathrm{a}} \pm 0.00$ & $6.33^{\mathrm{a}} \pm 0.00$ & $7.31^{\mathrm{a}} \pm 0.01$ & $7.82^{\mathrm{a}} \pm 0.00$ & $8.11^{\mathrm{a}} \pm 0.004$ \\
\hline $1 \%$ OP & $5.84^{\mathrm{b}} \pm 0.01$ & $6.00^{\mathrm{b}} \pm 0.00$ & $6.11^{\mathrm{b}} \pm 0.00$ & $6.31^{\mathrm{b}} \pm 0.00$ & $6.61^{\mathrm{b}} \pm 0.00$ & $6.98^{\mathrm{b}} \pm 0.00$ \\
\hline $2 \%$ OP & $5.76^{\mathrm{bc}} \pm 0.004$ & $5.90^{\mathrm{cd}} \pm 0.00$ & $6.00^{\mathrm{c}} \pm 0.00$ & $6.23^{\mathrm{c}} \pm 0.00$ & $6.40^{\mathrm{d}} \pm 0.00$ & $6.81^{\mathrm{b}} \pm 0.00$ \\
\hline $1 \%$ LP & $5.80^{\mathrm{bc}} \pm 0.01$ & $5.95^{\mathrm{bc}} \pm 0.00$ & $6.03^{\mathrm{c}} \pm 0.00$ & $6.30^{\mathrm{b}} \pm 0.00$ & $6.58^{\mathrm{c}} \pm 0.00$ & $6.92^{\mathrm{c}} \pm 0.00$ \\
\hline $2 \%$ LP & $5.71^{\mathrm{c}} \pm 0.01$ & $5.85^{\mathrm{d}} \pm 0.00$ & $5.97^{\mathrm{c}} \pm 0.00$ & $6.22^{\mathrm{c}} \pm 0.01$ & $6.37^{\mathrm{e}} \pm 0.00$ & $6.63^{\mathrm{e}} \pm 0.00$
\end{tabular}

All values are mean of triplicate determinations \pm standard deviation (SD). Mean values in the same column bearing the same superscript do not differ significantly $(\mathrm{P}>0.05) . \mathrm{OP}=$ Orange Peel and $\mathrm{LP}=$ Lemon Peel

Table.7 Instrumental color values of beef patties as affected by addition of citrus peel powder during refrigerated storage at $4 \pm 1{ }^{\circ} \mathrm{C}$ for 15 days

\begin{tabular}{|c|c|c|c|c|c|c|c|}
$\begin{array}{c}\text { Beef } \\
\text { patty } \\
\text { Samples }\end{array}$ & Parameter & \multicolumn{7}{|c|}{ Refrigerated Storage (day) } \\
\hline Control & $L^{*}$ & $52.07 \pm 0.02$ & $53.88 \pm 0.04$ & $56.03 \pm 0.01$ & $56.75 \pm 0.02$ & $56.96 \pm 0.04$ & $57.27 \pm 0.06$ \\
\hline & $a^{*}$ & $09.11 \pm 0.01$ & $07.72 \pm 0.02$ & $06.41 \pm 0.03$ & $06.33 \pm 0.03$ & $06.02 \pm 0.01$ & $04.62 \pm 0.02$ \\
\hline & $b^{*}$ & $18.69 \pm 0.11$ & $17.31 \pm 0.01$ & $16.91 \pm 0.02$ & $16.68 \pm 0.03$ & $16.03 \pm 0.02$ & $13.23 \pm 0.05$ \\
\hline 1\% OP & $L^{*}$ & $56.40 \pm 0.02$ & $54.54 \pm 0.01$ & $56.68 \pm 0.54$ & $57.19 \pm 0.03$ & $57.38 \pm 0.00$ & $57.64 \pm 0.03$ \\
\hline & $a^{*}$ & $10.60 \pm 0.02$ & $08.72 \pm 0.03$ & $08.35 \pm 0.01$ & $08.27 \pm 0.00$ & $08.08 \pm 0.04$ & $07.14 \pm 0.03$ \\
\hline & $b^{*}$ & $19.23 \pm 0.04$ & $17.34 \pm 0.03$ & $17.37 \pm 0.06$ & $17.26 \pm 0.05$ & $16.99 \pm 0.02$ & $15.33 \pm 0.03$ \\
\hline & $L^{*}$ & $56.72 \pm 0.01$ & $56.94 \pm 0.01$ & $59.18 \pm 0.02$ & $59.58 \pm 0.04$ & $59.69 \pm 0.02$ & $59.95 \pm 0.03$ \\
\hline & $a^{*}$ & $12.93 \pm 0.08$ & $09.51 \pm 0.07$ & $08.68 \pm 0.15$ & $08.66 \pm 0.01$ & $08.37 \pm 0.02$ & $07.48 \pm 0.04$ \\
\hline & $b^{*}$ & $19.71 \pm 0.01$ & $18.66 \pm 0.02$ & $17.60 \pm 0.02$ & $17.53 \pm 0.02$ & $17.06 \pm 0.04$ & $15.87 \pm 0.02$ \\
\hline $1 \%$ LP & $L^{*}$ & $58.35 \pm 0.01$ & $58.57 \pm 0.01$ & $59.37 \pm 0.01$ & $59.78 \pm 0.03$ & $59.91 \pm 0.07$ & $60.01 \pm 0.01$ \\
\hline & $a^{*}$ & $11.16 \pm 0.05$ & $09.11 \pm 0.05$ & $08.46 \pm 0.06$ & $08.37 \pm 0.04$ & $08.14 \pm 0.03$ & $07.25 \pm 0.02$ \\
\hline & $b^{*}$ & $19.30 \pm 0.03$ & $17.47 \pm 0.00$ & $17.31 \pm 0.01$ & $17.27 \pm 0.03$ & $17.03 \pm 0.06$ & $15.52 \pm 0.08$ \\
\hline $2 \%$ LP & $L^{*}$ & $59.30 \pm 0.01$ & $58.61 \pm 0.05$ & $63.07 \pm 0.04$ & $63.26 \pm 0.04$ & $63.34 \pm 0.02$ & $63.53 \pm 0.01$ \\
\hline & $a^{*}$ & $13.27 \pm 0.03$ & $09.72 \pm 0.03$ & $09.09 \pm 0.05$ & $08.96 \pm 0.03$ & $08.73 \pm 0.02$ & $08.03 \pm 0.02$ \\
\hline & $b^{*}$ & $20.78 \pm 0.02$ & $18.68 \pm 0.02$ & $18.21 \pm 0.06$ & $18.05 \pm 0.05$ & $17.89 \pm 0.02$ & $16.35 \pm 0.06$ \\
\hline
\end{tabular}

All values are mean of triplicate determinations \pm standard deviation (SD). Mean values in the same column bearing the same superscript do not differ significantly $(\mathrm{P} \leq 0.05)$. $\mathrm{OP}=$ Orange Peel and $\mathrm{LP}=$ Lemon Peel. 
Int.J.Curr.Microbiol.App.Sci (2018) 7(4): 2703-2723

Table.8 Cooking characteristic means of the beef patties containing powder of orange and lemon peels during refrigerated storage at $4 \pm 1{ }^{\circ} \mathrm{C}$

\begin{tabular}{|c|c|c|c|}
\hline \multirow{2}{*}{$\begin{array}{c}\text { Beef patty } \\
\text { Samples }\end{array}$} & \multicolumn{3}{|c|}{ Refrigerated storage (day) } \\
\hline & Zero time & The third & The sixth \\
\hline \multicolumn{4}{|c|}{ Cooking yield \% } \\
\hline Control & $66.05^{\mathrm{e}} \pm 0.03$ & $60.12^{\mathrm{e}} \pm 0.03$ & $56.55^{\mathrm{e}} \pm 0.03$ \\
\hline $1 \% \mathrm{OP}$ & $71.17^{\mathrm{d}} \pm 0.05$ & $67.12^{\mathrm{d}} \pm 0.02$ & $63.55^{\mathrm{d}} \pm 0.03$ \\
\hline $2 \% \mathrm{OP}$ & $71.66^{\mathrm{b}} \pm 0.01$ & $68.86^{\mathrm{b}} \pm 0.04$ & $63.91^{b} \pm 0.02$ \\
\hline $1 \% \mathrm{LP}$ & $71.26^{\mathrm{c}} \pm 0.05$ & $67.71^{\mathrm{c}} \pm 0.05$ & $63.75^{\mathrm{c}} \pm 0.04$ \\
\hline $2 \% \mathrm{LP}$ & $72.28^{\mathrm{a}} \pm 0.11$ & $69.50^{\mathrm{a}} \pm 0.01$ & $64.09^{\mathrm{a}} \pm 0.01$ \\
\hline \multicolumn{4}{|c|}{ Moisture retention (\%) } \\
\hline Control & $53.26^{\mathrm{e}} \pm 0.02$ & $46.23^{\mathrm{e}} \pm 0.03$ & $41.72^{\mathrm{e}} \pm 0.02$ \\
\hline $1 \% \mathrm{OP}$ & $59.77^{d} \pm 0.58$ & $53.90^{\mathrm{d}} \pm 0.02$ & $50.74^{\mathrm{d}} \pm 0.03$ \\
\hline $2 \% \mathrm{OP}$ & $60.72^{b} \pm 0.01$ & $56.85^{b} \pm 0.03$ & $53.92^{b} \pm 0.02$ \\
\hline $1 \% \mathrm{LP}$ & $60.17^{c} \pm 0.04$ & $54.88^{\mathrm{c}} \pm 0.04$ & $51.80^{c} \pm 0.03$ \\
\hline $2 \% \mathrm{LP}$ & $61.34^{\mathrm{a}} \pm 0.09$ & $58.01^{\mathrm{a}} \pm 0.01$ & $55.06^{\mathrm{a}} \pm 0.00$ \\
\hline \multicolumn{4}{|c|}{ Fat retention (\%) } \\
\hline Control & $58.14^{\mathrm{d}} \pm 0.03$ & $51.13^{\mathrm{e}} \pm 0.03$ & $44.62^{\mathrm{e}} \pm 0.02$ \\
\hline $1 \% \mathrm{OP}$ & $63.80^{c} \pm 0.04$ & $59.80^{\mathrm{d}} \pm 0.02$ & $54.05^{\mathrm{d}} \pm 0.03$ \\
\hline $2 \% \mathrm{OP}$ & $65.46^{\mathrm{b}} \pm 0.01$ & $62.2^{b} \pm 0.03$ & $57.01^{b} \pm 0.02$ \\
\hline $1 \% \mathrm{LP}$ & $63.87^{\mathrm{c}} \pm 0.04$ & $60.74^{\mathrm{c}} \pm 0.04$ & $55.04^{\mathrm{c}} \pm 0.03$ \\
\hline $2 \% \mathrm{LP}$ & $65.81^{\mathrm{a}} \pm 0.10$ & $62.94^{\mathrm{a}} \pm 0.01$ & $57.97^{\mathrm{a}} \pm 0.00$ \\
\hline \multicolumn{4}{|c|}{ Shrinkage (\%) } \\
\hline Control & $11.66^{\mathrm{a}} \pm 0.12$ & $13.35^{\mathrm{a}} \pm 0.12$ & $15.79^{\mathrm{a}} \pm 0.17$ \\
\hline $1 \% \mathrm{OP}$ & $5.01^{b} \pm 0.13$ & $5.40^{\mathrm{b}} \pm 0.07$ & $7.08^{b} \pm 0.15$ \\
\hline $2 \% \mathrm{OP}$ & $3.75^{\mathrm{c}} \pm 0.10$ & $5.23^{\mathrm{c}} \pm 0.07$ & $5.47^{\mathrm{c}} \pm 0.12$ \\
\hline $1 \% \mathrm{LP}$ & $5.01^{b} \pm 0.17$ & $5.40^{\mathrm{b}} \pm 0.11$ & $6.96^{\mathrm{b}} \pm 0.21$ \\
\hline $2 \% \mathrm{LP}$ & $3.75^{\mathrm{c}} \pm 0.04$ & $5.23^{\mathrm{c}} \pm 0.06$ & $5.48^{\mathrm{c}} \pm 0.18$ \\
\hline
\end{tabular}

All values are mean of triplicate determinations \pm standard deviation (SD). Mean values in the same column bearing the same superscript do not differ significantly $(\mathrm{P}>0.05)$. $\mathrm{OP}=$ Orange Peel and $\mathrm{LP}=$ Lemon Peel.

Table.9 Sensory evaluation of the beef patties containing powder of orange and lemon peels during refrigerated storage at $4 \pm 1{ }^{\circ} \mathrm{C}$

\begin{tabular}{|c|c|c|c|c|c|c|c|}
\hline $\begin{array}{l}\text { Patty } \\
\text { Samples }\end{array}$ & Color & Appearance & Oder & Texture & Taste & Tenderness & $\begin{array}{c}\text { Overall- } \\
\text { Acceptability }\end{array}$ \\
\hline & \multicolumn{7}{|c|}{ Zero time } \\
\hline Control & $7.56^{\mathrm{e}} \pm 1.5$ & $7.19^{d} \pm 1.76$ & $7.25^{\mathrm{c}} \pm 1.39$ & $7.31^{c} \pm 1.40$ & $7.19^{c} \pm 1.76$ & $7.13^{\mathrm{e}} \pm 1.63$ & $7.69^{c} \pm 1.66$ \\
\hline $1 \% \mathrm{OP}$ & $8.06^{c} \pm 0.09$ & $7.94^{b} \pm 1.12$ & $7.38^{\mathrm{b}} \pm 1.50$ & $7.63^{b} \pm 0.96$ & $7.63^{b} \pm 1.50$ & $7.69^{c} \pm 0.79$ & $7.88^{b} \pm 1.63$ \\
\hline $2 \% \mathrm{OP}$ & $8.38^{b} \pm 0.96$ & $8.13^{a} \pm 1.15$ & $8.13^{\mathrm{a}} \pm 1.31$ & $7.88^{\mathrm{a}} \pm 1.26$ & $7.69^{b} \pm 1.25$ & $8.06^{\mathrm{b}} \pm 1.00$ & $7.94^{b} \pm 1.12$ \\
\hline $1 \% \mathrm{LP}$ & $7.69^{d} \pm 0.10$ & $7.69^{c} \pm 0.95$ & $7.44^{\mathrm{b}} \pm 1.15$ & $7.13^{\mathrm{d}} \pm 1.36$ & $7.06^{\mathrm{d}} \pm 1.61$ & $7.56^{\mathrm{d}} \pm 1.21$ & $7.19^{d} \pm 1.28$ \\
\hline \multirow[t]{2}{*}{$2 \% \mathrm{LP}$} & $8.50^{\mathrm{a}} \pm 1.21$ & $8.19^{a} \pm 1.47$ & $8.13^{\mathrm{a}} \pm 1.41$ & $7.81^{\mathrm{a}} \pm 1.17$ & $8.38^{\mathrm{a}} \pm 1.20$ & $8.19^{a} \pm 1.11$ & $8.31^{\mathrm{a}} \pm 1.14$ \\
\hline & \multicolumn{7}{|c|}{ The third day } \\
\hline Control & $7.00^{\mathrm{e}} \pm 1.00$ & $7.23^{\mathrm{e}} \pm 1.00$ & $6.92^{c} \pm 0.95$ & $6.77^{\mathrm{e}} \pm 1.79$ & $6.85^{\mathrm{c}} \pm 1.34$ & $6.77^{\mathrm{d}} \pm 1.42$ & $7.15^{\mathrm{d}} \pm 0.55$ \\
\hline $1 \% \mathrm{OP}$ & $7.23^{\mathrm{d}} \pm 1.24$ & $7.31^{\mathrm{d}} \pm 1.24$ & $7.54^{\mathrm{b}} \pm 0.97$ & $7.46^{\mathrm{d}} \pm 1.13$ & $7.77^{b} \pm 1.59$ & $7.08^{c} \pm 1.38$ & $7.85^{b} \pm 0.90$ \\
\hline $2 \% \mathrm{OP}$ & $8.23^{\mathrm{b}} \pm 1.01$ & $7.92^{\mathrm{b}} \pm 1.01$ & $8.08^{\mathrm{a}} \pm 0.95$ & $7.92^{\mathrm{b}} \pm 0.86$ & $8.15^{\mathrm{a}} \pm 0.80$ & $8.08^{a} \pm 1.32$ & $8.38^{a} \pm 0.87$ \\
\hline $1 \% \mathrm{LP}$ & $7.46^{\mathrm{c}} \pm 0.78$ & $7.54^{c} \pm 1.05$ & $6.92^{c} \pm 1.19$ & $7.69^{c} \pm 0.75$ & $6.69^{d} \pm 1.38$ & $7.38^{\mathrm{b}} \pm 1.39$ & $7.54^{\mathrm{c}} \pm 0.78$ \\
\hline \multirow[t]{2}{*}{$2 \% \mathrm{LP}$} & $8.31^{\mathrm{a}} \pm 1.03$ & $8.31^{\mathrm{a}} \pm 0.85$ & $8.15^{\mathrm{a}} \pm 0.80$ & $8.00^{\mathrm{a}} \pm 1.08$ & $7.77^{\mathrm{b}} \pm 1.17$ & $8.08^{a} \pm 0.64$ & $8.38^{a} \pm 0.77$ \\
\hline & \multicolumn{7}{|c|}{ The sixth day } \\
\hline Control & $5.75^{\mathrm{e}} \pm 1.66$ & $6.17^{\mathrm{e}} \pm 1.47$ & $5.83^{\mathrm{e}} \pm 1.34$ & $5.83^{\mathrm{e}} \pm 1.59$ & $5.50^{\mathrm{d}} \pm 1.57$ & $5.67^{\mathrm{e}} \pm 1.50$ & $6.17^{\mathrm{e}} \pm 0.58$ \\
\hline $1 \% \mathrm{OP}$ & $6.83^{\mathrm{d}} \pm 1.11$ & $6.92^{\mathrm{d}} \pm 1.08$ & $6.67^{\mathrm{d}} \pm 1.15$ & $6.92^{\mathrm{d}} \pm 1.16$ & $7.42^{\mathrm{b}} \pm 1.31$ & $7.17^{\mathrm{d}} \pm 1.11$ & $7.33^{d} \pm 0.49$ \\
\hline $2 \% \mathrm{OP}$ & $8.13^{\mathrm{b}} \pm 1.35$ & $8.08^{b} \pm 0.67$ & $7.92^{\mathrm{b}} \pm 1.00$ & $7.75^{\mathrm{b}} \pm 0.87$ & $7.75^{\mathrm{a}} \pm 1.06$ & $8.08^{b} \pm 0.79$ & $8.00^{b} \pm 0.60$ \\
\hline $1 \% \mathrm{LP}$ & $7.21^{c} \pm 1.34$ & $7.58^{\mathrm{c}} \pm 0.51$ & $7.00^{c} \pm 1.21$ & $7.58^{\mathrm{c}} \pm 0.79$ & $7.00^{c} \pm 1.04$ & $7.50^{c} \pm 1.17$ & $7.50^{c} \pm 0.48$ \\
\hline $2 \% \mathrm{LP}$ & $8.25^{\mathrm{a}} \pm 1.08$ & $8.58^{a} \pm 0.51$ & $8.17^{\mathrm{a}} \pm 0.72$ & $8.17^{\mathrm{a}} \pm 0.72$ & $7.42^{\mathrm{b}} \pm 1.24$ & $8.17^{\mathrm{a}} \pm 0.72$ & $8.58^{a} \pm 0.47$ \\
\hline
\end{tabular}

All values are mean of eleven repeated determinations \pm standard deviation (SD). Mean values in the same column bearing the same superscript do not differ significantly $(\mathrm{P}>0.05)$. $\mathrm{OP}=$ Orange Peel and $\mathrm{LP}=$ Lemon Peel. 
Table.10 Effect of incorporation of powder orange and lemon peels on the textural characteristics of the prepared beef patties during refrigerated storage at $4 \pm 1^{\circ} \mathrm{C}$ for 15 day

\begin{tabular}{|c|c|c|c|c|c|}
\hline \multirow{2}{*}{$\begin{array}{l}\text { Beef patties } \\
\text { Sample }\end{array}$} & Hardness & Springiness & Cohesiveness & Gumminess & Chewiness \\
\hline & \multicolumn{5}{|c|}{ Zero time day } \\
\hline Control & $5.74^{\mathrm{a}} \pm 0.04$ & $0.75^{\mathrm{d}} \pm 0.03$ & $1.06^{\mathrm{c}} \pm 0.01$ & $0.92^{\mathrm{c}} \pm 0.01$ & $8.15^{\mathrm{a}} \pm 0.06$ \\
\hline $1 \% 0 \mathrm{P}$ & $5.13^{\mathrm{d}} \pm 0.03$ & $0.86^{\mathrm{c}} \pm 0.04$ & $1.11^{\mathrm{b}} \pm 0.03$ & $0.99^{b} \pm 0.01$ & $7.65^{c} \pm 0.03$ \\
\hline $2 \% \mathrm{OP}$ & $5.44^{b} \pm 0.03$ & $0.92^{\mathrm{ab}} \pm 0.01$ & $1.17^{\mathrm{a}} \pm 0.01$ & $1.05^{\mathrm{a}} \pm 0.03$ & $7.91^{b} \pm 0.03$ \\
\hline $1 \% \mathrm{LP}$ & $5.03^{\mathrm{e}} \pm 0.03$ & $0.88^{\mathrm{bc}} \pm 0.01$ & $1.06^{\mathrm{c}} \pm 0.01$ & $1.00^{\mathrm{b}} \pm 0.01$ & $7.63^{\mathrm{c}} \pm 0.03$ \\
\hline \multirow[t]{2}{*}{$2 \% \mathrm{LP}$} & $5.32^{\mathrm{c}} \pm 0.01$ & $0.96^{\mathrm{a}} \pm 0.01$ & $1.14^{\mathrm{ab}} \pm 0.01$ & $1.07^{\mathrm{a}} \pm 0.01$ & $7.82^{\mathrm{b}} \pm 0.03$ \\
\hline & \multicolumn{5}{|c|}{ The third day } \\
\hline Control & $5.67^{\mathrm{a}} \pm 0.03$ & $0.67^{\mathrm{d}} \pm 0.03$ & $0.98^{\mathrm{b}} \pm 0.04$ & $1.18^{\mathrm{a}} \pm 0.04$ & $8.33^{\mathrm{a}} \pm 0.03$ \\
\hline $1 \% \mathrm{OP}$ & $5.08^{\mathrm{d}} \pm 0.01$ & $0.80^{\mathrm{c}} \pm 0.01$ & $1.05^{\mathrm{ab}} \pm 0.01$ & $1.08^{b} \pm 0.01$ & $7.75^{\mathrm{d}} \pm 0.06$ \\
\hline $2 \% \mathrm{OP}$ & $5.38^{\mathrm{b}} \pm 0.01$ & $0.87^{\mathrm{ab}} \pm 0.03$ & $1.11^{\mathrm{a}} \pm 0.04$ & $1.05^{\mathrm{b}} \pm 0.00$ & $8.00^{b} \pm 0.04$ \\
\hline $1 \% \mathrm{LP}$ & $4.97^{\mathrm{e}} \pm 0.03$ & $0.82^{\mathrm{bc}} \pm 0.01$ & $1.00^{b} \pm 0.02$ & $1.08^{b} \pm 0.01$ & $7.72^{\mathrm{d}} \pm 0.01$ \\
\hline \multirow[t]{2}{*}{$2 \% \mathrm{LP}$} & $5.29^{c} \pm 0.02$ & $0.91^{\mathrm{a}} \pm 0.01$ & $1.09^{\mathrm{a}} \pm 0.01$ & $1.06^{\mathrm{b}} \pm 0.01$ & $7.90^{c} \pm 0.01$ \\
\hline & \multicolumn{5}{|c|}{ The sixth day } \\
\hline Control & $5.56^{\mathrm{a}} \pm 0.01$ & $0.57^{\mathrm{c}} \pm 0.06$ & $0.86^{\mathrm{c}} \pm 0.02$ & $1.48^{\mathrm{a}} \pm 0.07$ & $8.53^{\mathrm{a}} \pm 0.03$ \\
\hline $1 \% 0 P$ & $4.99^{\mathrm{d}} \pm 0.01$ & $0.73^{\mathrm{b}} \pm 0.03$ & $0.95^{\mathrm{b}} \pm 0.04$ & $1.20^{\mathrm{b}} \pm 0.02$ & $7.85^{\mathrm{d}} \pm 0.02$ \\
\hline $2 \% \mathrm{OP}$ & $5.29^{b} \pm 0.03$ & $0.80^{\mathrm{ab}} \pm 0.01$ & $1.02^{\mathrm{a}} \pm 0.01$ & $1.16^{\mathrm{b}} \pm 0.01$ & $8.09^{b} \pm 0.03$ \\
\hline $1 \% \mathrm{LP}$ & $4.88^{\mathrm{e}} \pm 0.04$ & $0.75^{\mathrm{b}} \pm 0.02$ & $0.90^{\mathrm{ab}} \pm 0.01$ & $1.21^{\mathrm{b}} \pm 0.03$ & $7.82^{\mathrm{d}} \pm 0.01$ \\
\hline \multirow[t]{2}{*}{$2 \% \mathrm{LP}$} & $5.21^{\mathrm{c}} \pm 0.02$ & $0.85^{\mathrm{a}} \pm 0.03$ & $1.01^{\mathrm{a}} \pm 0.00$ & $1.17^{\mathrm{b}} \pm 0.03$ & $7.99^{\mathrm{c}} \pm 0.03$ \\
\hline & \multicolumn{5}{|c|}{ The ninth day } \\
\hline Control & $5.42^{\mathrm{a}} \pm 0.04$ & $0.455^{\mathrm{d}} \pm 0.05$ & $0.71^{\mathrm{c}} \pm 0.03$ & $1.98^{\mathrm{a}} \pm 0.02$ & $8.75^{\mathrm{a}} \pm 0.03$ \\
\hline $1 \% \mathrm{OP}$ & $4.90^{d} \pm 0.02$ & $0.64^{\mathrm{c}} \pm 0.01$ & $0.85^{\mathrm{b}} \pm 0.03$ & $1.41^{\mathrm{b}} \pm 0.01$ & $7.98^{\mathrm{d}} \pm 0.01$ \\
\hline $2 \% \mathrm{OP}$ & $5.21^{\mathrm{b}} \pm 0.03$ & $0.72^{\mathrm{ab}} \pm 0.01$ & $0.93^{\mathrm{a}} \pm 0.03$ & $1.33^{\mathrm{c}} \pm 0.00$ & $8.21^{\mathrm{b}} \pm 0.03$ \\
\hline $1 \% \mathrm{LP}$ & $4.80^{\mathrm{e}} \pm 0.01$ & $0.67^{\mathrm{bc}} \pm 0.03$ & $0.80^{\mathrm{b}} \pm 0.01$ & $1.42^{b} \pm 0.04$ & $7.94^{\mathrm{d}} \pm 0.04$ \\
\hline \multirow[t]{2}{*}{$2 \% \mathrm{LP}$} & $5.13^{c} \pm 0.03$ & $0.78^{\mathrm{a}} \pm 0.03$ & $0.92^{\mathrm{a}} \pm 0.01$ & $1.35^{\mathrm{c}} \pm 0.01$ & $8.10^{c} \pm 0.06$ \\
\hline & \multicolumn{5}{|c|}{ The twelfth day } \\
\hline Control & $4.37^{\mathrm{c}} \pm 0.01$ & $0.27^{\mathrm{d}} \pm 0.03$ & $0.32^{\mathrm{c}} \pm 0.04$ & $2.58^{\mathrm{a}} \pm 0.04$ & $9.02^{\mathrm{a}} \pm 0.04$ \\
\hline $1 \% \mathrm{OP}$ & $4.20^{\mathrm{d}} \pm 0.02$ & $0.49^{c} \pm 0.04$ & $0.64^{\mathrm{b}} \pm 0.01$ & $1.88^{\mathrm{b}} \pm 0.01$ & $8.16^{\mathrm{cd}} \pm 0.03$ \\
\hline $2 \% \mathrm{OP}$ & $4.60^{\mathrm{a}} \pm 0.01$ & $0.60^{b} \pm 0.01$ & $0.81^{\mathrm{a}} \pm 0.01$ & $1.54^{\mathrm{c}} \pm 0.04$ & $8.39^{\mathrm{b}} \pm 0.11$ \\
\hline $1 \% \mathrm{LP}$ & $4.09^{\mathrm{e}} \pm 0.00$ & $0.53^{\mathrm{c}} \pm 0.02$ & $0.59^{\mathrm{b}} \pm 0.01$ & $1.90^{\mathrm{b}} \pm 0.01$ & $8.12^{\mathrm{d}} \pm 0.02$ \\
\hline \multirow[t]{2}{*}{$2 \% \mathrm{LP}$} & $4.54^{\mathrm{b}} \pm 0.04$ & $0.67^{\mathrm{a}} \pm 0.03$ & $0.82^{\mathrm{a}} \pm 0.02$ & $1.55^{\mathrm{c}} \pm 0.02$ & $8.27^{\mathrm{bc}} \pm 0.01$ \\
\hline & \multicolumn{5}{|c|}{ The fifteenth day } \\
\hline Control & $2.26^{\mathrm{c}} \pm 0.04$ & $0.16^{\mathrm{d}} \pm 0.04$ & $0.20^{c} \pm 0.01$ & $3.48^{\mathrm{a}} \pm 0.07$ & $9.33^{\mathrm{a}} \pm 0.03$ \\
\hline $1 \% \mathrm{OP}$ & $3.05^{\mathrm{b}} \pm 0.06$ & $0.38^{\mathrm{c}} \pm 0.02$ & $0.53^{\mathrm{b}} \pm 0.02$ & $2.49^{\mathrm{b}} \pm 0.03$ & $8.26^{\mathrm{d}} \pm 0.04$ \\
\hline $2 \% \mathrm{OP}$ & $3.59^{\mathrm{a}} \pm 0.06$ & $0.51^{\mathrm{b}} \pm 0.01$ & $0.72^{\mathrm{a}} \pm 0.01$ & $2.07^{\mathrm{c}} \pm 0.03$ & $8.57^{b} \pm 0.04$ \\
\hline $1 \% \mathrm{LP}$ & $2.94^{b} \pm 0.03$ & $0.43^{\mathrm{c}} \pm 0.00$ & $0.49^{b} \pm 0.03$ & $2.50^{\mathrm{b}} \pm 0.08$ & $8.25^{\mathrm{d}} \pm 0.06$ \\
\hline $2 \% \mathrm{LP}$ & $3.51^{\mathrm{a}} \pm 0.03$ & $0.58^{\mathrm{a}} \pm 0.01$ & $0.73^{\mathrm{a}} \pm 0.01$ & $2.07^{\mathrm{c}} \pm 0.06$ & $8.44^{\mathrm{c}} \pm 0.01$ \\
\hline
\end{tabular}

All values are mean of triplicate determinations \pm standard deviation (SD). Mean values in the same column bearing the same superscript do not differ significantly (P>0.05). OP: Orange Peel and LP: Lemon Peel 
Fig.1 Thiobarbituric acid reactive substances (TBARS) change of beef patties during refrigerated storage at $4^{\circ} \mathrm{C}$ for 15 days

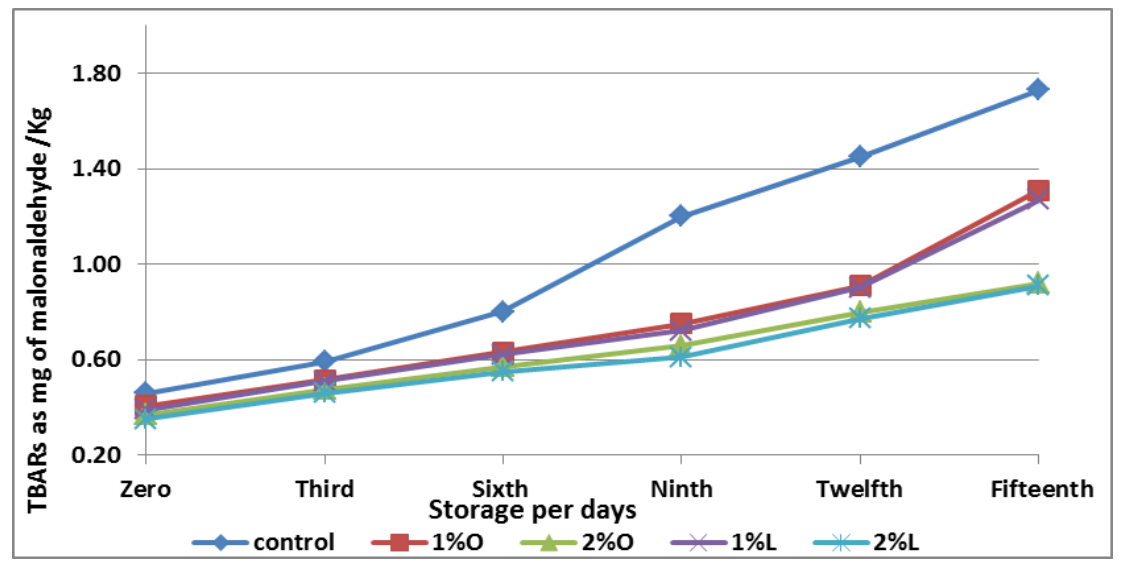

Fig.2 Total volatile basic nitrogen (TVBN) changes of beef patties refrigerated storage at $4^{\circ} \mathrm{C}$ for 15 days

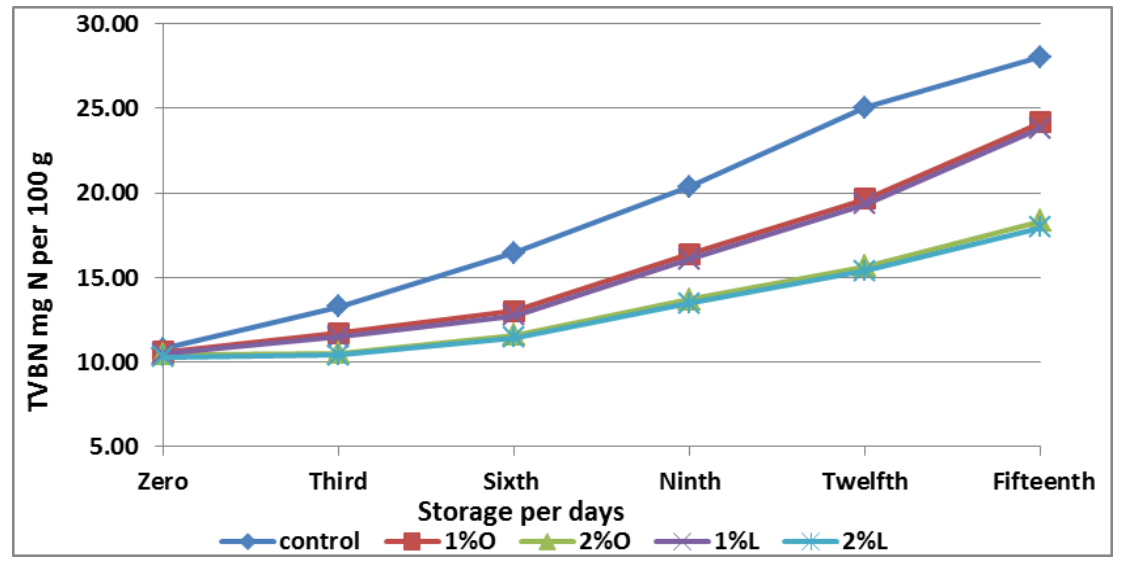

Fig.3 Changes radical scavenging activity (DPPH \%) values

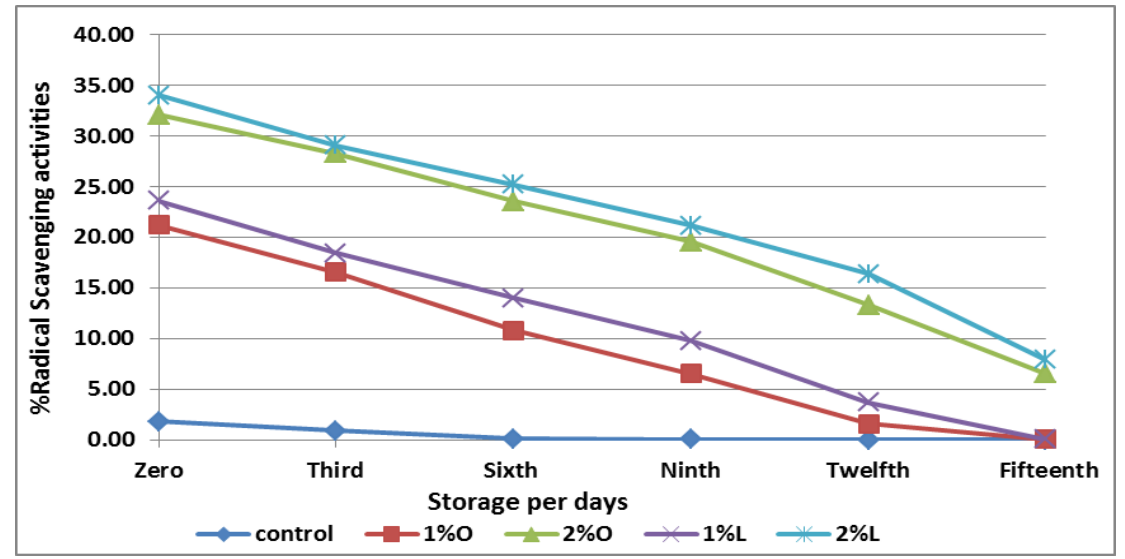


Fig.4 Total plate count changes of beef patty samples during refrigerated storage at $4 \pm 1{ }^{\circ} \mathrm{C}$ for 15 days (as $\log 10 \mathrm{CFUgm}^{-1}$ )

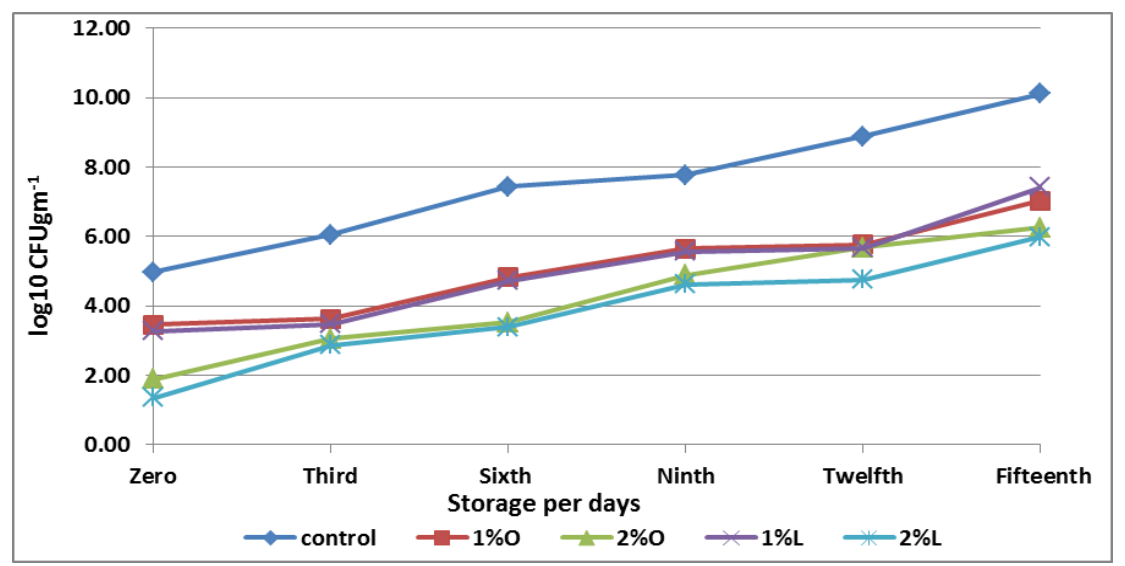

Fig. $5 \mathrm{pH}$ changes of beef patties during refrigerated storage at $4 \pm 1^{\circ} \mathrm{C}$ for 15 days

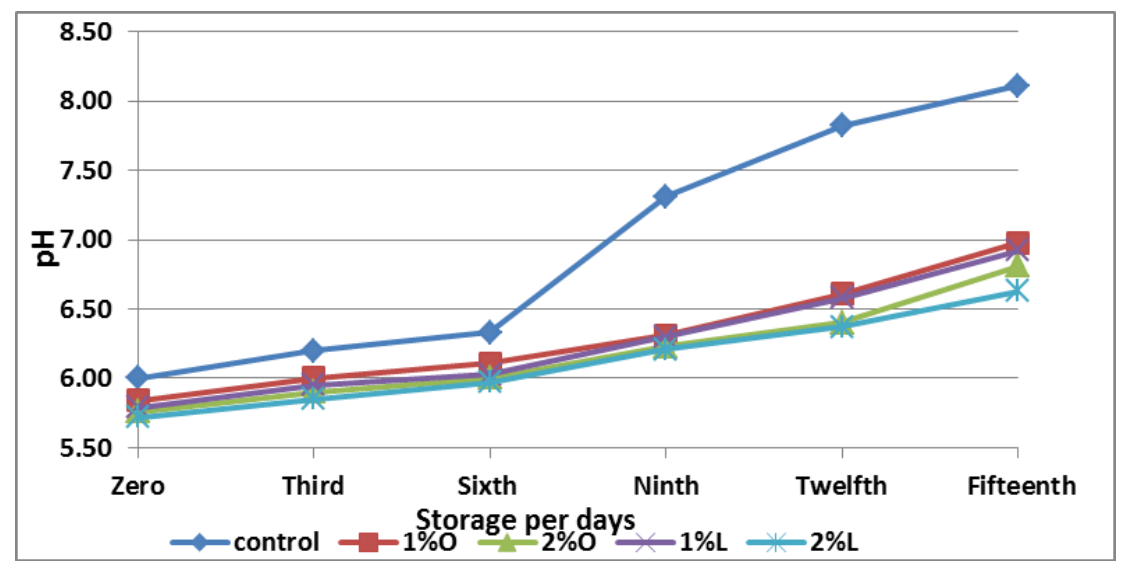

Mixing of OP or LP affected all color values relative to the control. 1 and $2 \%$ OP addition to the patties sample affected the color parameters values during the storage period i.e. lightness $\left(\mathrm{L}^{*}\right)$ values was increased to reach $(57.64$ and 59.95$)$ at $15^{\text {th }}$ day of storage. Meanwhile, $\mathrm{a}^{*}$ (redness) values decreased compared to control along the storage period to be (7.14 and 7.48) respectively. Also, the $\mathrm{b}^{*}$ (Yellowness) were of lower values than the control to be (15.33 and15.87).

The same effect was noticed with 1 and $2 \%$ LP and the lightness $\left(\mathrm{L}^{*}\right)$ values at the end of storage were increased to be $(60.01$ and
63.53). Moreover, the $\mathrm{b}^{*}$ (Yellowness) and $\mathrm{a}^{*}$ (redness) color acquired low values relative to the control and gained (15.52 and 16.35) at the end of storage period.

A decrease in $\left(b^{*}\right)$ and $\left(a^{*}\right)$ values of beef patties containing natural antioxidants has been reported by Ashour et al., (2014) who reported that over storage time, the $a^{*}$ values of all patties sample decreased and becoming less red or brown due to metmyoglabin formation. The yellowness $\left(b^{*}\right)$ values followed similar trend decreasing to the day 15. Also a decrease in $\left(b^{*}\right)$ values of beef patties containing natural antioxidants has 
been reported by Rojas and Brewer, (2008). Addition of any type of albedo at any concentration increased surface $b^{*}$ and $a^{*}$ values. This increase in $b^{*}$ value is related to the incorporation of yellowness and redness components present in lemon albedo to a studied burgers (Aleson-Carbonell et al., 2005).

\section{Cooking characteristics}

The obtained results are tabulated in Table 8 . Generally, it was noticed that cooking yield \% increased in beef patties incorporated with orange or lemon peels powder. Control sample recorded the significant lowest cooking yield. The cooking yield $(\%)$ of the control sample decreased from $66.05 \%$ at zero time of storage to be $56.55 \%$ at the $6^{\text {th }}$ day. The cooking yields of the formulated beef patties sample mixed with 1 or $2 \%$ OP were increased at zero time, relative to the control, and have 71.17 and $71.66 \%$ respectively.

At $6^{\text {th }}$ day their yields decreased to 63.55 and $63.91 \%$ respectively. Nearly the same effect was noticed for the formulated patties sample mixed with $1 \% \mathrm{LP}$; but the increase in cooking yield of 2\% LP sample was the greatest at zero time and at $6^{\text {th }}$ day $(72.28$ and $64.09 \%$ ) compared with the control and other formulated samples. The results of cooking determinants indicated that the control shows significantly $(\mathrm{p} \leq 0.05)$ lower cooking yield than 1 or $2 \%$ orange and lemon peel powder samples.

The moisture retention $\%$ of the formulated patties sample ( 1 or $2 \%$ OP or LP) increased at zero time relative the control. However, the storage time decreased the moisture retention $\%$ from zero till $6^{\text {th }}$ day of storage for all studied samples. The increase in moisture retention of $2 \% \mathrm{LP}$ sample was found the greatest at zero time and at $6^{\text {th }}$ day.
The same trend was noticed for fat retention $\%$ of the studied samples. The control sample was of lowest fat retention $\%$ and its retention decreased by the increasing of the storage period. Fat retention $\%$ of the beef patties sample was increased by adding OP or LP relative to the control sample; however the increase of fat retention $\%$ in $2 \%$ OP or LP was greater than the $\%$ increase in case of $1 \%$ OP and LP samples. Also, fat retention of the formulated samples was decreased by increasing the storage period from zero to $6^{\text {th }}$ day. This decrease in fat retention $\%$ was greater in cases of $2 \%$ OP or LP sample at the $6^{\text {th }}$ day.

The shrinkage $(\% \mathrm{~s})$ of the control sample at zero time and at $6^{\text {th }}$ day of storage was 11.66 and increased to 15.79 . This $\%$ was decreased for all the formulated samples at zero time and its decrease was greater in case of $2 \%$ OP or LP samples. Also the increase of shrinkage $\%$ was noticed by extending of storage time. At $6^{\text {th }}$ day the shrinkage of $2 \%$ OP or LP sample was of low \% than either the control or $1 \%$ OP or LP samples. This may be due to fat separation and water released which occurred during cooking and decreasing in water holding capacity.

Increase in cooking yield could be attributed to the increase in emulsion stability and due to the high ability of powder citrus peel to retain moisture and fat in the matrix. This finding is supported by Aleson-Carbonell et al., (2005), on the incorporation of lemon albedo fibers in beef patties formulation which shows that dietary fibers increased cooking yield, because of their ability to keep moisture and fat in the formulation. RochaGarza and Zayas, (1996) reported that, in meat products, quality attributes such as texture, structural binding and yield are determined by the ability of the protein matrix to retain water and bind fat. There were same relationship between moisture retention, fat 
retention and cooking yield with the addition levels of powder citrus peel to the beef patties formulations.

\section{Sensory evaluation}

The results of the sensory analysis are presented in Table 9. The mean values of the appearance, color, texture and tenderness were evaluated to determine overall acceptability. Beef patties incorporating 1 or $2 \%$ citrus peel powder was of high sensory attributes (color, appearance, odor, texture, taste and tenderness) than control sample at zero time. Meanwhile, these sensory attributes were increased by increasing the storage time. At $3^{\text {rd }}$ day of storage, the sensory attributes of the $2 \%$ OP and LP samples were noticed to be more than the corresponding $1 \%$ formulations. The same validation was also noticed at $6^{\text {th }}$ day of storage i.e. $2 \%$ OP and LP samples were noticed to be more acceptable than the corresponding $1 \%$ samples.

Regarding the overall-acceptability of the studied samples it was found that at zero day of storage the control sample was (7.69), this overall-acceptability increased gradually for the formulated samples. At $3^{\text {rd }}$ day of storage the overall-acceptability of the control sample decreased relative to its corresponding at zero days. Worthy to note that the $2 \%$ OP and LP formulated samples were more accepted than $1 \%$ OP and LP samples. Also 2\% LP was of more acceptability than the formulated $2 \% \mathrm{OP}$ sample. At six days of storage the overallacceptability of the control sample was of lowest acceptability (6.17), this acceptability increased for the formulated samples, but still the 2\% OP and LP samples having the great acceptability followed with $1 \%$ corresponding samples. Thus, it can be concluded that overall acceptability scores of the formulated samples increased with the increasing levels of citrus peel. However, beef patties containing $2 \%$ OP was scored slight tastefully by the panelists than the corresponding LP samples.

\section{Texture profile analysis}

Textural characteristics are important in the production of processed meat products because they effect on consumer acceptability. Spoilage of meat products contributes to deterioration of texture and changes in flavor and color.

Texture profile analyses results of control and $(1 \%, 2 \%)$ of either OP or LP formulated beef meat patties samples from zero time till $15^{\text {th }}$ day time are depicted in Table 10. The hardness value of control sample was significantly $(p \geq 0.05)$ higher, except at $15^{\text {th }}$ storage day, as compared to the other meat patties samples mixed with (1 or $2 \%$ ) of orange or lemon peels powders. Among all the formulated samples, the hardness values increased significantly $(\mathrm{p} \leq 0.05)$ as the $\%$ of orange or lemon peels powders increased i.e. $2 \%$ s OP and LP was of increased hardness values than the $1 \%$ corresponding samples.

In general, from zero till day 15, $1 \%$ lemon peel samples were of lowest hardness values and significantly of lower $(\mathrm{p} \leq 0.05)$ mean values than other studied samples including control. This hardness reduction of the formulated samples compared to control sample might be attributed to the incorporation of orange and lemon peels powder in patties which resulted in the decreased protein binding. High moisture retention might also be responsible for this hardness reduction as cleared by Huda et al., (2014). Similar results were also obtained by Aleson-Carbonell et al., (2005) and Comer \& Dempster, (1981), whereas burgers with added albedo (at any type and concentration) were less hard and gummier than the control. This hardness reduction could be related to 
the dilution effect of albedo in meat protein systems.

Also, the dilution effect of nonmeat ingredients in meat protein systems primarily accounted for soft texture. Gregg et al., (1993) found a high correlation between fat content and hardness in bologna sausages.

The tested samples had significantly higher cohesiveness values in comparison to control during all the storage period. The cohesiveness values of the formulated samples were increased gradually for 1, 2\% OP samples then reduced in case of $1 \%$ LP and increased again for $2 \%$ LP sample (Table $10)$.

The same trend was nearly observed all over the storage period. Non-significant difference $(\mathrm{P}>0.05)$ in cohesiveness values was observed among the samples. This agreed with the findings of Aleson-Carbonell et al., (2003) who reported that the increase of lemon albedo levels increased product cohesiveness $(p \leq 0.05)$ but the control was higher than other samples.

The springiness values of $2 \%$ lemon peel sample was significantly $(p \leq 0.05)$ higher than control from zero to the $15^{\text {th }}$ day of storage. However, a non-significant ( $p \geq 0.05)$ difference was observed between $(1 \%, 2 \%)$ OP and LP sample. The cooking process of product with added citrus peel powder could lead to some modifications in their structure, which could cause an increase in the springiness of treatment products as compared to control. Similar result was observed in beef burger incorporated with lemon albedo which had higher springiness value as compared to control (Aleson-Carbonell et al., 2005).

Gumminess values for the formulated samples were significantly higher compared to control through the investigated storage period. At $15^{\text {th }}$ day of storage the gumminess of $1 \& 2 \%$
OP and LP samples were nearly of the same values. Gumminess values decreased with the increasing levels of powder citrus peel although the difference was non-significant. Aleson-Carbonell et al., (2005) observed a similar increasing trend in the gumminess values of beef burger incorporated with lemon albedo.

The chewiness values of the control had significantly higher values all over the storage period compared to the values of formulated samples. Also, during the storage period (from zero till $15^{\text {th }}$ day) it was noticed that $1 \%$ OP or LP samples were of low chewiness values than $2 \%$ formulated samples. AlesonCarbonell et al., (2005) also reported decrease in chewiness values of beef burger incorporated with lemon albedo.

Orange and lemon peels may be viable functional ingredients for different food products. Meat products can be modified into more "healthier" form by adding beneficial ingredients for health, or by removing or reducing harmful components. The effectiveness of adding orange or lemon peels powder at two levels (1 and $2 \%$ ) on some quality properties of the prepared meat patties during refrigerated storage at $4 \pm 1^{\circ} \mathrm{C}$ for 15 days was investigated. These quality characteristics were studied and discussed. Therefore, the conclusion of this investigation suggested potential use of orange and lemon peels as natural food additives for improving quality and safety in meat products.

\section{References}

Alahakoon, A.U., Sik Bae, Y., Kim, H.J., Jung, S., Jayasena, D.D., Yong, H.I., Kim, S.H. and Jo, C. (2013). The effect of citrus and onion peel extracts, calcium lactate, and phosvitin on microbial quality of seasoned chicken breast meat. CNU Journal of Agricultural Science, 40(2): 131-137. 
Aleson-Carbonell, L., Ferna'ndez-Lo'pez, J., Sayas-Barbera', E., Sendra, E. and Pe'rez-Alvarez, J.A. (2003). Utilization of lemon albedo in dry-cured sausages. Journal of Food Science, 68: 18261830.

Aleson-Carbonell, L., Fernandez-Lopez, J., Perez-Alvarez, J.A. and Kuri, V. (2005). "Functional and sensory effects of fibre-rich ingredients on breakfast fresh sausages". Food Science and Technology International, 11(2): 89-97.

APHA, (2001). American Public Health Associtation. Compendium of methods for the microbiological examination of foods. Downes FP, Ito K, Eds. American Public Health Associtation: Washington, DC: USA; 4th Edt.

Ashour, M.M.S., Moawad, R.K. and Bareh, G.F. (2014). Quality Enhancement and Shelf-Life Extension of Raw Beef Patties Formulated with Lactate/Thyme Essential Oil during Refrigerated Storage. Journal of Applied Sciences Research, 9(13): 6699-6709.

Ayala-Zavala, J.F., Vega-Vega, V., RosasDomínguez, C., Palafox-Carlos, H., Villa- Rodríguez, J.A., Siddiqui, M.W., Dávila-Aviña, J.E. and GonzálezAguilar, G.A. (2011). Agro-industrial potential of exotic fruit by-products as a source of food additives. Food Research International, 44(7): 1866-1874.

Bochi, V.C., Weber, J., Ribeiro, C.P., Victório, A.M. and Emanuelli, T. (2008). Fish burgers with silver catfish (Rhamdia quelen) filleting residue. Bioresource Technology, 99: 88448849.

Braddock, R.J. (1995). By-products of citrus fruits. Food Technology, 49: 74-77.

Brake, N.C. and Fennema, O.R. (1999). Lipolysis and lipid oxidation in frozen minced mackerel as related to $\mathrm{Tg}$, molecular diffusion and presence of gelatin. J. Food Sci., 64(1): 25-32.
Brunton, N. P., Cronin, D. A., Monahan, F. J. and Durcan, R. (2000). A comparison of solid-phase microextraction (SPME) fibres for measurement of hexanal and pentanal in cooked turkey. Food Chemistry, 68: 339-345.

Camo, J., Beltrán, J.A. and Roncalés, P. (2008). Extension of the display life of lamb with an antioxidant active packaging. Meat Sci., 80: 1086-1091.

Chen, H.H., chiu, E.M. and Huang, J.R. (1997). Color and gel - forming properties of horse mackerel (Trachurus Japonucus) as related to washing condition. Journal of Food Science, 62: 985-991.

Claus, J.R. and Sørheim, O. (2006). Preserving pre-rigor meat functionality for beef patty production. Meat Science, 73: 287-294.

Comer, F.W. and Dempster, S. (1981). Functionality of fillers and meat ingredients in comminuted meat products. Canadian Institute of Food Science and Technology Journal, 14: 295-303.

Das, A.K., Rajkumar, V. and Dwivedi, D.K. (2011). Antioxidant effect of curry leaf (Murraya koenigii) powder on quality of ground and cooked goat meat. International Food Research Journal, 18: 563-569.

Difco-Manual. (1998). Culture Media and Ingredients, Difco Lab. (ed.) Dehydrated $11^{\text {th }}$ Ed., Division of Becton Dickimson and Company. Sparks, Maryland, USA.

EL-Desouky, A.I., Bahlol, H.E.M. and Sharoba, A.M.A. (2006). Effect of some essential oils and preservatives on the growth of E. coli o157 and quality of refrigerated minced meat. Annals of Agricultural Sciences, Moshtohor, 44(4):1675-1695.

ES, (1694/2005): Egyptian standards for minced meat. Egyptian Organization for 
Standardization and Quality Control. Ministry of Industry. Cairo, Egypt.

Fernández-López, J., Pérez-Alvarez, J.A. and Fernández-López, J.A. (1997). Thiobarbituric acid test for monitoring lipid oxidation in meat. Food Chemistry, 59:345-353.

Fernandez-Lopez, J., Sendra-Nadal, E., Navarro, C., Sayas, E., Viuda- Martos, M. and Perez-Alvarez, J.A. (2009). Storage stability of a high dietary fibre powder from orange by-products. International Journal of Food Science and Technology, 44(4): 748-756.

Figuerola, F., Hurtado, M.L., Estévez, A. M., Chiffelle, I. and Asenjo, F. (2005). Fibre concentrates from apple pomace and citrus peel as potential fibre sources for food enrichment. Food Chemistry, 91(3): 395-401.

Frazier, W.C. and Foster, E.M. (1950). Laboratory manual for food microbiology. Burgess publishing Co., Minnesota, U.S.A

Gregg, L.L., Claus, J.R., Hackney, C.R. and Marriot, N.G. (1993). Low fat, high added water bologna from massaged, minced batter. Journal of Food Science, 58: 259-264.

Hamm, R. (1986). Functional properties of the myofibrillar system and their measurements, In: Bechtel P. J. (Ed.), Muscle as food, Academic Press Inc., New York, USA, pp. 135-199.

Hanan H. A. and Dalia A. Z. (2013). Utilization of Fruit by-Product in Ground Meat Preservation. Food Science and Quality Management, 11:49-60.

Hassan, I.M., Hayam M.I., Abdel Fattah A.A. and Ahmed, A.M.H. (2017). Citrus sinensis and Citrus aurantiifolia Peel Extracts: Antibacterial, Antioxidant Activity and Total phenolic. Int. J. Curr. Microbiol. App. Sci., 6(12): 3983-3998.
Hayam M.I. and Ferial M.A. (2013). Effect of Adding Lemongrass and Lime Peel Extracts on Chicken Patties Quality. Journal of Applied Sciences Research, 9(8): 5035-5047.

Hayes, J.E., Stepanyan, V., Allen, P., O'Grady, M.N. and Kerry, J.P. (2010). Effect of lutein, sesamol, ellagic acid and olive leaf extract on the quality and shelf-life stability of packaged raw minced beef patties. Meat Science, 84: 613-620.

Huda, B.A., Shahnaz, P., Sajad, A.R., Rehana, A. and Massarat, H. (2014). Effect of incorporation of apple pomace on the physico-chemical, sensory and textural properties of mutton nuggets. International Journal of Advanced Research, 2(4): 974-983.

ICMSF (International Commission on Microbiological Specification for Foods), 1986. Microorganisms in Foods 2. Sampling for microbiological analysis: Principles and specific applications, 2nd Ed. University of Toronto Press, Toronto, Canada. Available at: http://www.icmsf.iit.edu/ pdf/icmsf2.pdf

Jiménez-Colmenero, F., Herrero, A., Cofrades, S. and Ruiz-Capillas, C. (2012). Meat and functional foods. In Y. H. Hui (Ed.), Handbook of meat and meat processing (2nd ed.). Boca Raton: CRC Press. Taylor and Francis Group, pp. 225-248.

Kethireddipalli, P., Hung, Y.C., Phillips, R.D. and McWatters, K.H. (2002). Evaluating the role of cell material and soluble protein in the functionality of cowpea (Vigna unguiculata) pastes. Journal of Food Science, 67: 53-59.

Kim, H., Miller, D.K., Lee, Y.J. and Kim, B.Y.H. (2016). Effects of soy hull pectin and insoluble fiber on physicochemical and oxidative characteristics of fresh and 
frozen/thawed beef patties. Meat Science, 117: 63-67.

Klangpetch, W., Phromsurin, K., Hannarong, K., Wichaphon, J. and Rungchang, S. (2016). Antibacterial and antioxidant effects of tropical citrus peel extracts to improve the shelf life of raw chicken drumettes. International Food Research Journal, 23(2): 700-707. http://www. ifrj.upm.edu.my

Marı'n, F.R., Martınez, M., Uribesalgo, T., Castillo, S. and Frutos, M.J. (2002). Changes in nutraceutical composition of lemon juices according to different industrial extraction systems. Food Chemistry, 78: 319-324.

Mexis, S.F., Chouliara, E. and Kontominas, M.G. (2012). Shelf life extension of ground chicken meat using an oxygen absorber and a citrus Extract. LWTFood Science and Technology, 49: 2127.

Mielnik, M. B., Olsen, E., Vogt, G., Adeline, D. and Skrede, G. (2006). Grape seed extract as antioxidant in cooked, cold stored turkey meat. Food Science and Technology, 39:191-198.

Moawad, R.K., Salem, S.A., Morsi, H.H., Mohamed, H.S. and El- Magoli, S.B. (2000). Chemical composition, quality attributes of ostrich meat produced in Egypt in comparison to beef and chicken meat. Mansoura Journal of Agricultural Science, 25 (12):79377950.

Pavelková, A., Kačániová, M., Hleba, L., Petrová, J., Pochop, J. and Čuboň, J. (2013). Sensory Evaluation of Chicken Breast Treated with Oregano Essential Oil. Animal Sci. Biotech., 46(2): 379383.

Pearson, D. (1991).The chemical analysis of food. Churchill: New York, London, pp: 374-410. Cited from African Journal of Food Science, 3(10): 316-319.
Podolak, K., Setser, C.S., Kastner, C.L. and Zayas, J.F. (1997). Aroma, color and texture of ground beef patties treated with fumaric and lactic acids. Journal of Food Quality, 20: 513-524.

Ramful, D., Tarnus, E., Aruoma, O.I., Bourdon, E. and Bahorun, T. (2011). Polyphenol composition, vitamin C content and antioxidant capacity of Mauritian citrus fruit pulps. Food Research International, 44: 2088 2099.

Rocha-Garza, A.E. and Zayas, J.F. (1996). Quality of broiled beef patties supplemented with wheat germ protein flour. Journal of Food Science, 61: 418421.

Rojas, M.C. and Brewer, M.S. (2008). Effect of natural antioxidants on oxidative stability of frozen vacuum packaged beef and pork. Journal of Food Quality, 31: 173-185.

Sallam, K.I. and Samejima, K. (2004). Microbiological and chemical quality of ground beef treated with sodium lactate and sodium chloride during refrigerated storage. Lebensmittel-Wissenschaft \& Technologie, 37: 865-871.

Sangnark, A. and Noomhorm, A. (2003). Effect of particle sizes on functional properties of dietary fibre prepared from sugarcane bagasse. Food Chemistry, 80: 221-229.

Sharma, K., Mahato, N., Cho, M.H. and Lee, Y.R. (2017). Converting citrus wastes into value-added products: Economic and environmentally friendly approaches. Nutrition, 34: 29-46.

Sherwin, E.R. (1998). Oxidation and antioxidants in fat and oil processing. Journal of the American Oil Chemists Society, 55: 809-814.

Viuda-Martos, M., Ruiz-Navajas, Y., MartinSánchez, A., Sánchez-Zapata, E., Fernández-López, J., Sendra, E., SayasBarberá, E., Navarro, C. and Pérez- 
Álvarez J.A. (2012). Chemical, physicochemical and functional properties of pomegranate (Punica gramatum L.) bagasses powder co-product. Journal of Food Engineering, 110: 220-224.

Wang, H., Cao, G. and Prior, R. (1996). Total antioxidant capacity of fruit. Journal of Agricultural and Food Chemistry, 44: 701-705.

Watts, B.M., Yamaki, G., Jeffery, L.E. and Elias, L.G. (1989). Basic Sensory Methods for Food Evaluation. 1st Edition, The International Development Research Center Publ., Ottawa, Canada.

WCRF/AICR (2007). World cancer research fund / American institute for cancer research, food, nutrition, physical activity and the prevention of cancer: A global perspective. Washington, DC: AICR (accessed 23 January 2013).

WHO (2015) Diet, nutrition and the prevention of chronic diseases. WHO Technical Re- port Series 916. Geneva: WHO Library Cataloguing Publication Data.
World Health Organization (2003). Joint WHO/FAO Expert Consultation on Diet, Nutrition and the Prevention of Chronic Diseases. Diet, nutrition, and the prevention of chronic disease; WHO Library Cataloguing-in-Publication Data. WHO Technical Report Series, No. 916. Geneva. https://www. bioscience.org/2017 /v9s/af/480/list.htm

Yi, Z., Yu, Y., Liang, Y. and Zeng, B. (2008). In vitro antioxidant and antimicrobial activities of the extract of Pericarpium Citri Reticulatae of a new Citrus cultivar and its main flavonoids, LWTFood Science and Technology, 41: 597603.

Zuhaib F. B., Pathak, V. and Hina F. (2013). Effect of refrigerated storage on the quality characteristics of microwave cooked chicken seekh kababs extended with different non-meat proteins. J Food Sci Technol., 50(5):926-933.

\section{How to cite this article:}

Hayam M. Ibrahim, Ibrahim M. Hassan and Ahmed A.M. Hamed. Application of Lemon and Orange Peels in Meat Products: Quality and Safety. Int.J.Curr.Microbiol.App.Sci. 7(04): 27032723. doi: https://doi.org/10.20546/ijcmas.2018.704.309 